\title{
High Technology Readiness Level Techniques for Brushless Direct Current Motors Failures Detection: A Systematic Review
}

\author{
Vito Mario Fico ${ }^{1, *(\mathbb{D})}$, María Ángeles Martín Prats ${ }^{2}$ [D and Carmelina Ierardi ${ }^{3}$ (i) \\ 1 Skylife Engineering, 41092 Seville, Spain \\ 2 Escuela Técnica Superior de Ingeniería, Electronics Engineering Department, Universidad de Sevilla, \\ 41092 Seville, Spain; mmprats@us.es \\ 3 Engineering Department, Universidad Loyola Andalucía, 41704 Seville, Spain; cierardi@uloyola.es \\ * Correspondence: vito.fico@skylife-eng.com
}

Received: 3 February 2020; Accepted: 18 March 2020; Published: 1 April 2020

\begin{abstract}
Many papers related to this topic can be found in the bibliography; however, just a modest percentage of the introduced techniques are developed to a Technology Readiness Level (TRL) sufficiently high to be implementable in industrial applications. This paper is focused precisely on the review of this specific topic. The investigation on the state of the art has been carried out as a systematic review, a very rigorous and reliable standardised scientific methodology, and tries to collect the articles which are closer to a possible implementation. This selection has been carefully done with the definition of a series of rules, drawn to represent the adequate level of readiness of fault detection techniques which the various articles propose.
\end{abstract}

Keywords: failure; PMSM; detection; diagnosis; BLDC; brushless; systematic review

\section{Introduction}

The topic of the present review is subjected to a growing interest, both from the academic and the industrial worlds, due to the parallel increase of the usage of electric machines for high reliability tasks as motoring of electric vehicles and actuation of flight surface for the future More Electric Aircrafts.

Above all, when aerospace applications are involved, reliability becomes of vital importance; indeed, the performance of flight actuators on a damaged aircraft is not as important as ensuring that the remaining actuators continue operation until the aircraft can land safely. In most cases, an adequate level of reliability can be reached only by using diagnostic tools [1].

The availability of an accurate and efficient mean of condition monitoring and machine fault diagnosis can be of paramount importance, as it improves the reliability and stability of the plant and at the same time it reduces costs, ideally leading to a system without programmed maintenance. Statistical studies [2] show that expected reliability can be improved up to 5-6 percentage points with the use of monitoring.

In this context arises the need to precisely know the evolution and the current state of the literature about the fault detection and diagnosis techniques for Brushless DC (BLDC) and in particular which techniques are closer to a possible implementation, i.e., which techniques have the highest Technology Readiness Level (TRL).

In the area of engineering, and especially for aerospace engineering, the narrative revision is usually preferred. In this kind of review, the authors decide which papers include in the survey, based on their wide knowledge and experience and offering a personal point of view and interpretation of the chosen theme. 
The SR is a rigorous standardised scientific methodology, used to produce reliable literature reviews, mainly recognised by its objectivity. It is employed with exceptional results in many areas, including bio-science [3,4], computer science [5] and in recent years particularly in software engineering [6,7]. In particular, these last papers and the work proposed by [8] have been used as guides to undertake the systematic review in this work.

In fact, the first objective of this work is precisely to adapt the guidelines mentioned above to our field, while the second objective is to apply the systematic review to a specific topic: high TRL techniques for BLDC motors failures detection.

To be more precise, the authors are interested in those detection techniques that are not restricted to a particular machine or with special set-ups, configurations, loads or motor manoeuvres. Furthermore the techniques shall have been tested at various operation point and the algorithm shall have tested with success for at least one of some cases later described in the inclusion criteria. Concluding, in order to be accepted in the systematic review, the paper shall demonstrate that the proposed algorithm is capable to discern between healthy and faulty motor. These constitute, mainly, the inclusion criteria for the studies appearing in the review.

The fundamental scope of this review is indeed to detect which techniques are presently being profitably used for motor fault detection and diagnosis and to provide the industry with some high readiness level and tested techniques. In this prospect, most of the inclusion and exclusion criteria have been defined to focus the investigation on those techniques with demonstrated fault detection performances at various operation points and easily automatable or already automated.

An additional question considered in this SR has been the possibility to embed in the motor body, the hardware needed for fault detection. Although most articles are focused on the detection by utilising commonly measured variables (mainly speed, current, voltage) some authors have elaborated fault detection techniques based on the analysis of images from external cameras or sensitive accelerometers. Those techniques are appropriate to be implemented only in particular applications [1] and have been discarded from the scope of the present work.

After the screening of more than 3000 possible papers, only 44 primary studies have been found to satisfy the aforementioned criteria. The authors have carefully revised those papers and have collected the following data: the type of fault detected, the technique that was used for the detection and the sensors used, the inclusion of experiments or simulations, if the technique has been tested at different operation points (diverse speed or loads or in the best case a combination of both), the working condition (stationary or not) and some other limitations/advantages.

This information is then gathered in a feature table, which is an useful strategy to get a complete, rigorous and objective view of the chosen topic. At the end of the process, the research questions initially formulated are answered, providing a full perspective of the topic [8].

The SR consists of three sequential phases, each of which is subdivided in turn into sub-phases, as detailed below [7]:

1. Planning the review

- identification of the need

- research questions

- review protocol

- evaluating protocol

2. Conducting the review

- selection of primary studies

- $\quad$ study quality assessment

- extraction and synthesis of data

3. Reporting the review

- $\quad$ specifying dissemination mechanisms

- formatting the main report 
- evaluating the report

The rest of the paper is organised as follows.. Section 2 presents the description and the adaptation to our case of planning phase of the SR. Conducting and reporting of the systematic review are given in Sections 3 and 4 respectively. Finally, the conclusions are drawn in Section 5. Additionally, in Appendix A is given a definition of the main terminology used along the document.

\section{Planning}

The first step of the systematic review consists in planning, which is the foundation of the entire revision. It is at this stage that the main tools are developed, such as the Boolean function, the inclusion and exclusion criteria, the choice of the different databases in which to carry out the research and above all the development and evaluation of a protocol that regulates all the phases.

The need to undertake a systematic review, arises first of all because the research topic is very wide and a rigorous method was needed to correctly extract the needed information. As said, in the engineering field this type of methodology is not usual because, even by being scientific and rigorous, it is difficult and complicated to carry out. Currently there is no systematic review on the fault detection techniques for brushless DC motors, and in reality there is not even a traditional revision so detailed on the chosen theme (Should be clarified that this sentence is referred to the reviews taking into account the readiness level of the technique.).

\subsection{Research Questions}

Once the concrete topic has been identified, there are some criteria that help to clearly formulate research questions. Among the most used criteria in other sectors there are the criteria called PICOC (Population, Intervention, Comparison, Outcome, Context). In this work we have considered those presented in [8] and adapted to our case.

In this case, just some of these criteria have been used to formulate and process the questions that this SR is trying to answer. In the final section of the review, defined as reporting, there is a sub-section called Discussion (Section 4.1) where the relative answers are discussed and analysed.

The questions formulated for the present work are listed below:

RQ.1: Which are the most common faults of BLDC motors?

RQ.2: Which parameters are used for fault detection in BLDC motors?

RQ.3: Which type of failure can be detected by each technique?

RQ.4: Which technique requires less computational power?

RQ.5: Which technique requires less sensors?

RQ.6: Which technique gives the best results for each type of failure?

\subsection{Review Protocol}

The revision protocol is nothing more than a set of rules and criteria to be followed during all the stages, in order to reduce the bias and make the SR as objective as possible. In the bioscience field, the protocol is sometimes recorded in a prospective register, such as PROSPERO (https:/ / www.crd. york.ac.uk/prospero/). Unfortunately, these type of registers do not exist in the aerospace field.

A very important aspect to be considered for the SR is the clarity wherewith the protocol is exposed and elaborated, as at least two persons are involved in the review drafting. A common, but very time consuming, approach consists in the implementation of the SR by two independent persons, who carry out the part of the conducting and reporting separately and then compare and discuss the obtained results. Another method, that is the one used in this work, is that a person performs all the phases individually and a second person randomly checks some data, as for example, some of the rows of the features tables (Tables 1-5). 
Table 1. Features table (a)

\begin{tabular}{|c|c|c|c|c|c|c|c|c|}
\hline Cite & Year & Fault Type & Technique Used & Sensors Used & $\begin{array}{l}\text { Experiments or } \\
\text { Simulations }\end{array}$ & $\begin{array}{c}\text { Various } \\
\text { Speed/Loads }\end{array}$ & $\begin{array}{l}\text { Working } \\
\text { Condition }\end{array}$ & $\begin{array}{l}\text { Limitations/ } \\
\text { Advantages }\end{array}$ \\
\hline$[9]$ & 2019 & $\begin{array}{l}\text { Armature } \\
\text { faults }\end{array}$ & $\begin{array}{l}\text { Parameters } \\
\text { Estimation }\end{array}$ & $\begin{array}{l}\text { Voltage, } \\
\text { Current and } \\
\text { Position } \\
\text { sensors }\end{array}$ & Both & Both & $\begin{array}{l}\text { Stationary } \\
\text { conditions }\end{array}$ & $\begin{array}{l}\text { It propose indicators deduced from symmetrical component of } \\
\text { phase currents in the reference frame. The method has been } \\
\text { validate at various speed, loads and short circuit resistance } \\
\text { magnitude for ITSC and at constant speed, load, resistance } \\
\text { magnitude for PPSC. The algorithm computational load is } \\
\text { nos specified. }\end{array}$ \\
\hline [10] & 2019 & $\begin{array}{l}\text { Permanent } \\
\text { Magnetic } \\
\text { faults }\end{array}$ & $\begin{array}{l}\text { Model, AI and } \\
\text { neural-network-based } \\
\text { techniques }\end{array}$ & $\begin{array}{l}\text { Voltage and } \\
\text { Current } \\
\text { sensors }\end{array}$ & Both & Various Speed & $\begin{array}{l}\text { Stationary } \\
\text { conditions }\end{array}$ & $\begin{array}{l}\text { Experimentally tested with } 5 \text { motor conditions ( } 1 \text { healthy, } 4 \\
\text { faulty) with good detection performances. Proposes two failure } \\
\text { extraction methods and compares them. Training time and } \\
\text { computational load not specified. }\end{array}$ \\
\hline [11] & 2019 & $\begin{array}{l}\text { Mechanical } \\
\text { faults }\end{array}$ & MCSA & $\begin{array}{l}\text { Voltage and } \\
\text { Current } \\
\text { sensors }\end{array}$ & Both & Both & $\begin{array}{l}\text { Stationary } \\
\text { conditions }\end{array}$ & $\begin{array}{l}\text { Uses wavelet decomposition of the current signal and an adaptive } \\
\text { filter to estimate and remove the fundamental component. Tested } \\
\text { using two case studies, i.e., broken magnet and eccentricity fault, } \\
\text { automatic fault classification with SVM and average accuracy of } \\
96 \% \text {. Training time and computational load not specified. }\end{array}$ \\
\hline [12] & 2019 & $\begin{array}{l}\text { Permanent } \\
\text { Magnetic } \\
\text { faults }\end{array}$ & $\begin{array}{l}\text { Other (Hall Effect } \\
\text { Sensors } \\
\text { analysis) }\end{array}$ & $\begin{array}{l}\text { Hall Effect } \\
\text { Sensors }\end{array}$ & Experiments & Various Speed & $\begin{array}{l}\text { Non-Stationary } \\
\text { conditions }\end{array}$ & $\begin{array}{l}\text { Method capable of detecting bearing and permanent magnets } \\
\text { faults by analysing respectively the cascade DWT-CWT transform } \\
\text { of the speed signal and the kurtosis index of the duty cycle signal } \\
\text { of the hall sensor output. Electrically independent from the motor. } \\
\text { Influence of load not specified. Computational load not specified. }\end{array}$ \\
\hline$[1]$ & 2019 & $\begin{array}{l}\text { Permanent } \\
\text { Magnetic } \\
\text { faults }\end{array}$ & $\begin{array}{l}\text { Other (Signals } \\
\text { Similarity } \\
\text { Analysis) }\end{array}$ & $\begin{array}{l}\text { Voltage and } \\
\text { Current } \\
\text { sensors }\end{array}$ & Both & Various Speed & $\begin{array}{l}\text { Stationary } \\
\text { Conditions }\end{array}$ & $\begin{array}{l}\text { The method has been tested with FEM simulations and } \\
\text { experimentally with good results. The test effect of torque on } \\
\text { the method has not benn evaluated. The method can be used only } \\
\text { for multipole motors. }\end{array}$ \\
\hline [13] & 2019 & $\begin{array}{l}\text { Armature } \\
\text { faults }\end{array}$ & $\begin{array}{l}\text { Electromagnetic } \\
\text { field monitoring }\end{array}$ & $\begin{array}{l}\text { Tunneling } \\
\text { Magnetoresistive } \\
\text { sensors }\end{array}$ & Both & Both & $\begin{array}{l}\text { Stationary } \\
\text { Conditions }\end{array}$ & $\begin{array}{l}\text { The method is capable of detecting both location and severity of } \\
\text { inter-turn short-circuit by sensing the stray magnetic field outside } \\
\text { the stator yoke. It needs the installation of TM sensors around the } \\
\text { motor body. Computational load not specified. }\end{array}$ \\
\hline [14] & 2018 & $\begin{array}{l}\text { Mechanical } \\
\text { faults }\end{array}$ & $\begin{array}{l}\text { Other (Angular } \\
\text { Resample) }\end{array}$ & $\begin{array}{l}\text { Voltage and } \\
\text { Current } \\
\text { sensors }\end{array}$ & Experiments & Both & $\begin{array}{l}\text { Non-Stationary } \\
\text { conditions }\end{array}$ & $\begin{array}{l}\text { Method based on the angular resample of speed obtained with } \\
\text { a sensorless observer. Computational load not specified. Torque } \\
\text { variation not specified. }\end{array}$ \\
\hline [15] & 2018 & $\begin{array}{l}\text { Permanent } \\
\text { Magnetic } \\
\text { faults }\end{array}$ & $\begin{array}{l}\text { Other } \quad \text { (Voltage } \\
\text { Angle) }\end{array}$ & $\begin{array}{l}\text { Voltage and } \\
\text { Current } \\
\text { sensors }\end{array}$ & Both & Various Speed & $\begin{array}{l}\text { Stationary } \\
\text { Conditions }\end{array}$ & $\begin{array}{l}\text { The method takes advantage from the variations of the } \\
\text { voltage angle observed during demagnetisation and inter-turns } \\
\text { short faults to identify their presence. The method is } \\
\text { temperature-dependant. A clear detection threshold is not } \\
\text { defined. Computational load not specified. }\end{array}$ \\
\hline
\end{tabular}


Table 2. Features table (b)

\begin{tabular}{|c|c|c|c|c|c|c|c|c|}
\hline Cite & Year & Fault Type & Technique Used & Sensors used & $\begin{array}{l}\text { Experiments or } \\
\text { Simulations }\end{array}$ & $\begin{array}{c}\text { Various } \\
\text { Speed/Loads }\end{array}$ & $\begin{array}{l}\text { Working } \\
\text { Condition }\end{array}$ & $\begin{array}{l}\text { Limitations/ } \\
\text { Advantages }\end{array}$ \\
\hline [16] & 2018 & Armature faults & $\begin{array}{l}\text { Parameters } \\
\text { Estimation }\end{array}$ & $\begin{array}{l}\text { Current and } \\
\text { Voltage } \\
\text { sensors }\end{array}$ & Both & Both & $\begin{array}{l}\text { Stationary } \\
\text { condition }\end{array}$ & $\begin{array}{l}\text { The method is affected by the magnitude of the stator current, } \\
\text { should be used in constant torque conditions. }\end{array}$ \\
\hline [17] & 2017 & Mechanical faults & $\begin{array}{l}\text { Electromagnetic } \\
\text { field monitoring, } \\
\text { search coils, coils } \\
\text { wound around } \\
\text { motor shafts }\end{array}$ & Search coil & Simulations & $\begin{array}{l}\text { Various } \\
\text { Speeds }\end{array}$ & $\begin{array}{l}\text { Stationary } \\
\text { Conditions }\end{array}$ & $\begin{array}{l}\text { The method is independent from motor variables, but needs the } \\
\text { search coil to be installed on the stator. }\end{array}$ \\
\hline [18] & 2017 & Armature faults & $\begin{array}{l}\text { Model, AI, } \\
\text { and neural-network } \\
\text {-based techniques, } \\
\text { Parameters } \\
\text { Estimation }\end{array}$ & $\begin{array}{l}\text { Current, } \\
\text { Voltage and } \\
\text { Speed sensors }\end{array}$ & Experiments & Both & $\begin{array}{l}\text { Stationary } \\
\text { Conditions }\end{array}$ & $\begin{array}{l}\text { This method has been tested experimentally on an aeronautical } \\
\text { motor, but the experiment set-up has not been presented. } \\
\text { The algorithm is very fast }(\approx 15 \mathrm{msec}) \text {, but the computation time } \\
\text { for the features is not taken into account. Also it needs a large } \\
\text { database for training the algorithm. }\end{array}$ \\
\hline [19] & 2017 & $\begin{array}{l}\text { Permanent } \\
\text { Magnetic and } \\
\text { Mechanical faults }\end{array}$ & $\begin{array}{l}\text { Model, AI, } \\
\text { and neural } \\
\text {-network-based } \\
\text { techniques }\end{array}$ & $\begin{array}{l}\text { Current } \\
\text { sensor }\end{array}$ & Experiments & Various Loads & $\begin{array}{l}\text { Stationary } \\
\text { Conditions }\end{array}$ & $\begin{array}{l}\text { Two failures introduced on an experimental platform and a 10-fold } \\
\text { validation of the algorithm is executed. The algorithm is fast ( } 30 \\
\text { msec), but the training time is not specified. }\end{array}$ \\
\hline$[20]$ & 2017 & Armature faults & $\begin{array}{l}\text { Parameters } \\
\text { Estimation }\end{array}$ & $\begin{array}{l}\text { Current and } \\
\text { Voltage } \\
\text { sensors }\end{array}$ & Both & Both & $\begin{array}{l}\text { Non-Stationary } \\
\text { Conditions }\end{array}$ & $\begin{array}{l}\text { The proposed method is just slightly dependent from the load } \\
\text { and speed. The authors also demonstrated robustness against } \\
\text { parameters variation and inaccuracies by introducing a threshold, } \\
\text { but the allowed tolerance is not specified and this quantity can } \\
\text { also depend on the motor. }\end{array}$ \\
\hline [21] & 2017 & Armature faults & MCSA & $\begin{array}{l}\text { Current and } \\
\text { Voltage } \\
\text { sensors }\end{array}$ & Both & Both & $\begin{array}{l}\text { Stationary } \\
\text { Conditions }\end{array}$ & $\begin{array}{l}\text { The proposed method is particularised for intermittent faults. } \\
\text { The test set-up is not presented. Tests at various loads and speeds } \\
\text { have been executed, but their influence on the method is not } \\
\text { specified. }\end{array}$ \\
\hline [22] & 2017 & Mechanical faults & $\begin{array}{l}\text { Other (Hall Effect } \\
\text { Sensors } \\
\text { analysis) }\end{array}$ & $\begin{array}{l}\text { Analogue or } \\
\text { Digital Hall } \\
\text { sensors }\end{array}$ & Both & Various Loads & $\begin{array}{l}\text { Stationary } \\
\text { Conditions }\end{array}$ & $\begin{array}{l}\text { The method is independent from speed and demonstrates only a } \\
\text { slight dependence from loads. The best accuracy is obtained with } \\
\text { analogue Hall effect sensor which are not common, even if the } \\
\text { authors provide an alternative based on digital Hall effect sensors. } \\
\text { This method can be used only if the Hall sensors are placed in the } \\
\text { radial direction. }\end{array}$ \\
\hline [23] & 2017 & $\begin{array}{c}\text { Permanent } \\
\text { Magnetic faults }\end{array}$ & $\begin{array}{l}\text { Other (Torque } \\
\text { Ripple Analysis) }\end{array}$ & Torque sensor & Both & Various Loads & $\begin{array}{l}\text { Stationary } \\
\text { Conditions }\end{array}$ & $\begin{array}{l}\text { No information is given about how the motor speed affects the } \\
\text { proposed method. A torque transducer is needed to apply the } \\
\text { algorithm. }\end{array}$ \\
\hline
\end{tabular}


Table 3. Features table (c)

\begin{tabular}{|c|c|c|c|c|c|c|c|c|}
\hline Cite & Year & Fault Type & Technique Used & Sensors Used & $\begin{array}{l}\text { Experiment or } \\
\text { Simulations }\end{array}$ & $\begin{array}{c}\text { Various } \\
\text { Speed/Loads }\end{array}$ & $\begin{array}{l}\text { Working } \\
\text { Condition }\end{array}$ & $\begin{array}{l}\text { Limitations/ } \\
\text { Advantages }\end{array}$ \\
\hline [24] & 2016 & $\begin{array}{l}\text { Armature } \\
\text { faults }\end{array}$ & $\begin{array}{l}\text { Parameters } \\
\text { estimation }\end{array}$ & $\begin{array}{l}\text { Current, } \\
\text { Voltage and } \\
\text { Speed sensor }\end{array}$ & Both & $\begin{array}{l}\text { Various } \\
\text { Speeds }\end{array}$ & $\begin{array}{l}\text { Non-Stationary } \\
\text { Conditions }\end{array}$ & $\begin{array}{l}\text { The method is based on a modified motor model. It is based on } \\
\text { computations in the rotating frame (dq). No information about how } \\
\text { the load affects the detection method is given. }\end{array}$ \\
\hline [25] & 2016 & $\begin{array}{l}\text { Armature } \\
\text { faults }\end{array}$ & $\begin{array}{l}\text { Parameters } \\
\text { Estimation }\end{array}$ & $\begin{array}{l}\text { Current and } \\
\text { Speed sensors }\end{array}$ & Experiments & $\begin{array}{l}\text { Various } \\
\text { speeds }\end{array}$ & $\begin{array}{l}\text { Stationary } \\
\text { Conditions }\end{array}$ & $\begin{array}{l}\text { The proposed fault index has a very reduced dependence from motor } \\
\text { speed. }\end{array}$ \\
\hline [26] & 2016 & $\begin{array}{l}\text { Mechanical } \\
\text { faults }\end{array}$ & $\begin{array}{l}\text { MCSA, Model, AI } \\
\text { and NN-based } \\
\text { techniques }\end{array}$ & $\begin{array}{l}\text { Current } \\
\text { Sensor }\end{array}$ & Experiments & $\begin{array}{l}\text { Various } \\
\text { Speeds }\end{array}$ & $\begin{array}{l}\text { Stationary } \\
\text { Conditions }\end{array}$ & $\begin{array}{l}\text { The implementation is very close to a real scenario, but in some } \\
\text { studied conditions the fail rate of the classifier is relatively high. }\end{array}$ \\
\hline [27] & 2016 & $\begin{array}{l}\text { Permanent } \\
\text { Magnetic } \\
\text { Faults }\end{array}$ & $\begin{array}{l}\text { Parameters } \\
\text { Estimation }\end{array}$ & $\begin{array}{l}\text { Current, } \\
\text { Speed and } \\
\text { Angle Sensors }\end{array}$ & Both & Both & $\begin{array}{l}\text { Non-Stationary } \\
\text { Conditions }\end{array}$ & $\begin{array}{l}\text { The method needs the knowledge of various motor parameters } \\
\text { and their variation (or incorrectness) can result in poor diagnosis } \\
\text { performances. The authors demonstrated good performances with } \\
\text { various demagnetisation levels and working conditions. }\end{array}$ \\
\hline [28] & 2016 & $\begin{array}{l}\text { Armature } \\
\text { faults }\end{array}$ & $\begin{array}{lr}\text { Other } & \text { (PWM } \\
\text { Ripple Current } & \\
\text { Measurements) }\end{array}$ & $\begin{array}{l}\text { Current and } \\
\text { Voltage } \\
\text { sensors }\end{array}$ & Both & Both & $\begin{array}{l}\text { Stationary } \\
\text { Conditions }\end{array}$ & $\begin{array}{l}\text { The method needs an electric model of the motor valid for high } \\
\text { frequencies. The author demonstrated good sensitivity also at low } \\
\text { speed. }\end{array}$ \\
\hline [29] & 2015 & $\begin{array}{l}\text { Mechanical } \\
\text { faults }\end{array}$ & $\begin{array}{l}\text { Noise and } \\
\text { Vibration } \\
\text { Monitoring, } \\
\text { Model, AI, NN } \\
\text { based techniques, } \\
\text { MCSA }\end{array}$ & $\begin{array}{l}\text { Current } \\
\text { sensor and } \\
\text { Accelerometer }\end{array}$ & Both & Both & $\begin{array}{l}\text { Non-Stationary } \\
\text { Conditions }\end{array}$ & $\begin{array}{l}\text { The method is capable to detect and distinguish different bearing } \\
\text { failures. Need an accelerometer to be placed close to the bearing. }\end{array}$ \\
\hline [30] & 2015 & $\begin{array}{l}\text { Mechanical } \\
\text { faults }\end{array}$ & $\begin{array}{l}\text { Model, } \\
\text { NN-based } \\
\text { techniques }\end{array}$ & $\begin{array}{l}\text { Current } \\
\text { sensor }\end{array}$ & Experiments & Both & $\begin{array}{l}\text { Stationary } \\
\text { Conditions }\end{array}$ & $\begin{array}{l}\text { The authors performed an extensive experiment campaign with good } \\
\text { results. From the images in the article, the damages reproduced on } \\
\text { the bearing appear to be considerable. }\end{array}$ \\
\hline [31] & 2015 & $\begin{array}{c}\text { Armature } \\
\text { faults }\end{array}$ & $\begin{array}{l}\text { Model, AI and } \\
\text { NN-based } \\
\text { techniques, } \\
\text { MCSA }\end{array}$ & $\begin{array}{l}\text { Current } \\
\text { sensor }\end{array}$ & Experiments & Both & $\begin{array}{l}\text { Stationary } \\
\text { Conditions }\end{array}$ & $\begin{array}{l}\text { High detection ratio. The frequency analysis is did with the FFT, this } \\
\text { means that during the } 12 \mathrm{~s} \text { of signal acquisition the motor speed and } \\
\text { load shall be constant. }\end{array}$ \\
\hline [32] & 2015 & $\begin{array}{c}\text { Armature } \\
\text { faults }\end{array}$ & $\begin{array}{l}\text { Electromagnetic } \\
\text { field monitoring, } \\
\text { Search Coils, } \\
\begin{array}{l}\text { Coils } \\
\text { around } \\
\text { shaft }\end{array}\end{array}$ & Search coil & Both & $\begin{array}{l}\text { Various } \\
\text { Speeds }\end{array}$ & $\begin{array}{l}\text { Stationary } \\
\text { Conditions }\end{array}$ & $\begin{array}{l}\text { The presented method is invasive for an already built motor } \\
\text { The detection time is very short }(3-5) \text { ms but it seems be dependent } \\
\text { on motor speed; furthermore the hardware used for computations is } \\
\text { not presented. }\end{array}$ \\
\hline [33] & 2015 & $\begin{array}{c}\text { Armature } \\
\text { faults }\end{array}$ & $\begin{array}{l}\text { Model, AI and } \\
\text { NN-based } \\
\text { techniques, } \\
\text { MCSA }\end{array}$ & $\begin{array}{l}\text { Current } \\
\text { sensors }\end{array}$ & Both & Both & $\begin{array}{l}\text { Stationary } \\
\text { Conditions }\end{array}$ & $\begin{array}{l}\text { The motor used for experiments has an inherent anomaly, but the } \\
\text { algorithm is capable to discern it from the short-circuit. The presented } \\
\text { method does not imply any previous knowledge on the motor. } \\
\text { They uses FFT, it implies that during the signal acquisition the } \\
\text { conditions need to be stationary. }\end{array}$ \\
\hline
\end{tabular}


Table 4. Features table (d)

\begin{tabular}{|c|c|c|c|c|c|c|c|c|}
\hline Cite & Year & Fault Type & Technique Used & Sensors Used & $\begin{array}{l}\text { Experiment or } \\
\text { Simulations }\end{array}$ & $\begin{array}{c}\text { Various } \\
\text { Speed/Loads }\end{array}$ & $\begin{array}{l}\text { Working } \\
\text { Condition }\end{array}$ & $\begin{array}{l}\text { Limitations/ } \\
\text { Advantages }\end{array}$ \\
\hline [34] & 2013 & $\begin{array}{c}\text { Permanent } \\
\text { Magnets faults }\end{array}$ & $\begin{array}{l}\text { Model, AI and } \\
\text { NN-based } \\
\text { techniques, } \\
\text { Parameters } \\
\text { Estimation }\end{array}$ & $\begin{array}{l}\text { Current, } \\
\text { Voltage and } \\
\text { Speed sensors }\end{array}$ & Experiments & Various loads & $\begin{array}{l}\text { Stationary } \\
\text { Conditions }\end{array}$ & $\begin{array}{l}\text { Proposes a method for demagnetisation. Comparison of the } \\
\text { proposed method with various other established methods. }\end{array}$ \\
\hline [35] & 2013 & $\begin{array}{c}\text { Armature, } \\
\text { Permanent } \\
\text { Magnets and } \\
\text { Mechanical Faults }\end{array}$ & $\begin{array}{l}\text { Model, } \\
\text { NN-based } \\
\text { techniques, } \\
\text { MCSA }\end{array}$ & $\begin{array}{l}\text { Current } \\
\text { sensors }\end{array}$ & Simulations & Both & $\begin{array}{l}\text { Stationary } \\
\text { Conditions }\end{array}$ & $\begin{array}{l}\text { The paper presents a good variety of motors, faults and working } \\
\text { conditions. The detection accuracy obtained is very high, but it } \\
\text { can be due to the use of clean signals from simulations. }\end{array}$ \\
\hline$[36]$ & 2013 & Armature faults & $\begin{array}{l}\text { Model, } \quad \text { AI } \\
\text { and NN-based } \\
\text { techniques }\end{array}$ & $\begin{array}{l}\text { Current and } \\
\text { Voltage } \\
\text { Sensors }\end{array}$ & Both & Both & $\begin{array}{l}\text { Stationary } \\
\text { Conditions }\end{array}$ & $\begin{array}{l}\text { The training of the AI has been executed with data from } \\
\text { both experiments and simulations. The method uses current } \\
\text { measurements in time domain with no need of frequency domain } \\
\text { transformation. The method is capable of detecting fault severity } \\
\text { and location. }\end{array}$ \\
\hline$[37]$ & 2013 & Armature faults & $\begin{array}{l}\text { Parameters } \\
\text { estimation }\end{array}$ & $\begin{array}{l}\text { Current, } \\
\text { Voltage and } \\
\text { Speed sensors }\end{array}$ & Both & Various loads & $\begin{array}{l}\text { Stationary } \\
\text { Conditions }\end{array}$ & $\begin{array}{l}\text { The method compares an estimated back-EMF with a reference } \\
\text { one for fault detection. The reference is obtained from a FEM } \\
\text { model or from an healthy machine. This method can be very } \\
\text { sensible to motor parameters change. The influence of the load is } \\
\text { not discussed. }\end{array}$ \\
\hline$[38]$ & 2013 & Armature faults & MCSA & $\begin{array}{c}\text { Current, } \\
\text { Voltage and } \\
\text { Speed sensors }\end{array}$ & Both & Both & $\begin{array}{l}\text { Non-Stationary } \\
\text { Conditions }\end{array}$ & $\begin{array}{l}\text { The proposed method has a low computational burden, but needs } \\
\text { access to the motor neutral point to be applied. }\end{array}$ \\
\hline [39] & 2011 & Mechanical faults & $\begin{array}{l}\text { Model, } \quad \text { AI } \\
\text { and NN-based } \\
\text { techniques }\end{array}$ & $\begin{array}{l}\text { Current, } \\
\text { Speed and } \\
\text { Torque } \\
\text { sensors, }\end{array}$ & Simulations & Both & $\begin{array}{l}\text { Non-Stationary } \\
\text { Conditions }\end{array}$ & $\begin{array}{l}\text { The method tries to detect mechanical faults by estimating the } \\
\text { bearing health status. A torque sensor is used, which is not usually } \\
\text { mounted in motors and the validation is carried out by simulation } \\
\text { without added noise. }\end{array}$ \\
\hline [40] & 2011 & Armature faults & $\begin{array}{l}\text { Parameters } \\
\text { estimation }\end{array}$ & $\begin{array}{c}\text { Current, } \\
\text { Voltage and } \\
\text { Speed sensors }\end{array}$ & Both & Both & $\begin{array}{l}\text { Non-Stationary } \\
\text { Conditions }\end{array}$ & $\begin{array}{l}\text { The back-EMF is estimated when the machine is healthy and then } \\
\text { frozen, which causes dependence on motor parameters changes } \\
\text { There is a model for compensate the inverter losses compensation. }\end{array}$ \\
\hline [41] & 2011 & Armature faults & $\begin{array}{l}\text { Other (High } \\
\text { Frequency } \\
\text { Injection) }\end{array}$ & $\begin{array}{l}\text { Current and } \\
\text { Angular } \\
\text { Position } \\
\text { sensors }\end{array}$ & Both & Various loads & $\begin{array}{l}\text { Stationary } \\
\text { Conditions }\end{array}$ & $\begin{array}{l}\text { The method has a very good resolution, but the detection is based } \\
\text { on a look-up table. This makes the algorithm ignore all the failures } \\
\text { (if any) present before the table creation. }\end{array}$ \\
\hline [42] & 2011 & Armature faults & MCSA & $\begin{array}{l}\text { Current } \\
\text { sensors }\end{array}$ & Experiments & Both & $\begin{array}{l}\text { Stationary } \\
\text { Conditions }\end{array}$ & $\begin{array}{l}\text { Capable of detecting two failures. Use the FFT for the frequency } \\
\text { analysis, but detect periods of stationarity of the motor. Use linear } \\
\text { interpolation to define the healthy comparison term. }\end{array}$ \\
\hline
\end{tabular}


Table 5. Features table (e)

\begin{tabular}{|c|c|c|c|c|c|c|c|c|}
\hline Cite & Year & Fault Type & Technique Used & Sensors Used & $\begin{array}{l}\text { Experiment or } \\
\text { Simulations }\end{array}$ & $\begin{array}{c}\text { Various } \\
\text { Speed/Loads }\end{array}$ & $\begin{array}{l}\text { Working } \\
\text { Condition }\end{array}$ & $\begin{array}{l}\text { Limitations/ } \\
\text { Advantages }\end{array}$ \\
\hline [43] & 2011 & $\begin{array}{l}\text { Armature and } \\
\text { Mechanical } \\
\text { faults }\end{array}$ & $\begin{array}{l}\text { Model, } \\
\text { NN-based } \\
\text { techniques }\end{array}$ & $\begin{array}{l}\text { Current and } \\
\text { Voltage senors }\end{array}$ & Experiments & Various Loads & $\begin{array}{l}\text { Stationary } \\
\text { Conditions }\end{array}$ & $\begin{array}{l}\text { Perform an interesting multi-class classification based on seven } \\
\text { parameters. The algorithm does not seem capable to classify } \\
\text { failures not present the training set. }\end{array}$ \\
\hline [44] & 2010 & $\begin{array}{l}\text { Mechanical } \\
\text { faults }\end{array}$ & $\begin{array}{l}\text { Model, } \\
\text { NN-based } \\
\text { techniques, } \\
\text { MCSA }\end{array}$ & Current sensors & Both & $\begin{array}{l}\text { Various loads } \\
\text { (Load } \\
\text { independence } \\
\text { demonstrated } \\
\text { analytically) }\end{array}$ & $\begin{array}{l}\text { Stationary } \\
\text { Conditions }\end{array}$ & Study on the impact of SNR. \\
\hline [45] & 2010 & $\begin{array}{l}\text { Armature } \\
\text { faults }\end{array}$ & $\begin{array}{l}\text { Model, } \\
\text { NN-based } \\
\text { techniques, } \\
\text { MCSA }\end{array}$ & Current sensors & Both & $\begin{array}{l}\text { Various loads } \\
\text { (Load } \\
\text { independence } \\
\text { demonstrated } \\
\text { analytically) }\end{array}$ & $\begin{array}{l}\text { Stationary } \\
\text { Conditions }\end{array}$ & $\begin{array}{l}\text { Study on the impact of SNR. Two failures studied, with fault } \\
\text { severity estimation. }\end{array}$ \\
\hline [46] & 2008 & $\begin{array}{l}\text { Armature } \\
\text { faults }\end{array}$ & $\begin{array}{l}\text { Model, } \quad \text { AI } \\
\text { and NN-based } \\
\text { techniques }\end{array}$ & $\begin{array}{l}\text { Current, Voltage } \\
\text { and Speed } \\
\text { sensors }\end{array}$ & Experiments & Various Loads & $\begin{array}{l}\text { Non-Stationary } \\
\text { Conditions }\end{array}$ & $\begin{array}{l}\text { Training of a neural-network to predict current and include initial } \\
\text { asymmetries. The predicted value of the current is used as a } \\
\text { reference to detect failures under load variations. }\end{array}$ \\
\hline$[47]$ & 2007 & $\begin{array}{l}\text { Mechanical } \\
\text { faults }\end{array}$ & MCSA & $\begin{array}{l}\text { Current and } \\
\text { Voltage sensors }\end{array}$ & Both & Both & $\begin{array}{l}\text { Non-Stationary } \\
\text { Conditions }\end{array}$ & $\begin{array}{l}\text { The experimental set-up is not described. There is a comparison } \\
\text { between three technique for time-frequency analysis and relative } \\
\text { fault detection. }\end{array}$ \\
\hline$[48]$ & 2007 & $\begin{array}{l}\text { Mechanical } \\
\text { faults }\end{array}$ & MCSA & $\begin{array}{l}\text { Current and } \\
\text { Voltage sensors }\end{array}$ & Both & Both & $\begin{array}{l}\text { Non-Stationary } \\
\text { Conditions }\end{array}$ & The experimental set-up is not described. \\
\hline [49] & 2007 & $\begin{array}{l}\text { Mechanical } \\
\text { faults }\end{array}$ & MCSA & $\begin{array}{l}\text { Current and } \\
\text { Voltage sensors }\end{array}$ & Both & $\begin{array}{l}\text { Various } \\
\text { Speeds }\end{array}$ & $\begin{array}{l}\text { Non-Stationary } \\
\text { Conditions }\end{array}$ & $\begin{array}{l}\text { The influence of load is not taken into account. The experimental } \\
\text { set-up is not described. }\end{array}$ \\
\hline$[50]$ & 2006 & $\begin{array}{c}\text { Armature, } \\
\text { Permanent } \\
\text { Magnets and } \\
\text { Mechanical } \\
\text { faults }\end{array}$ & MCSA & $\begin{array}{l}\text { Current and } \\
\text { Speed sensors }\end{array}$ & Experiments & Both & $\begin{array}{l}\text { Non-Stationary } \\
\text { Conditions }\end{array}$ & $\begin{array}{l}\text { Method for tracking the fault frequencies during variable speed } \\
\text { operations. The test set-up is not described. Various faults have } \\
\text { been implemented. }\end{array}$ \\
\hline$[51]$ & 2006 & $\begin{array}{l}\text { Mechanical } \\
\text { faults }\end{array}$ & MCSA & $\begin{array}{l}\text { Current and } \\
\text { Speed sensors }\end{array}$ & Both & Both & $\begin{array}{l}\text { Non-Stationary } \\
\text { Conditions }\end{array}$ & $\begin{array}{l}\text { Two methods presented based on different frequency tracking } \\
\text { algorithms. Real-time implementation with processor execution } \\
\text { time is also included. }\end{array}$ \\
\hline
\end{tabular}


One of the basic steps of the protocol is the creation of a Boolean function that comprehensively includes all the terms related to the chosen theme, including all the synonyms and terms that may be related to the words of interest for the topic. To carry out this research based on keywords, it is appropriate to deeply read about the theme to detect which words are most frequently used by the authors.

The articulate Boolean function created for this work is as follows:

((("brushless DC" OR "permanent magnet electrical") AND (motor OR
machine)) OR BLDC OR PMSM)
AND
(((condition OR health) AND monitoring) OR ((diagnosis
AND (fault OR $\quad$ OR failure))

The first part of the Boolean function defines the type of motor, while the second one defines the detection of the defect.

A difficulty encountered during the research is that the different bibliographic databases are not prepared for this kind of revision, as they do not allow certain researches or to search in certain fields of the papers. Indeed, the Boolean function based research was carried out in the title, abstract and keywords of the papers.

Due to the research restrictions of the databases, as specified in [52], and thanks to the good coverage of the editorials obtained shown in Table 6, the following databases have been used:

- IEEE Xplore Digital Library

- Scopus

- ACM Digital Library

- $\quad$ Science Direct

- Web of Science

Table 6. Databases coverage with respect to the content of the publishers: IE = IEEE, IT $=$ IET, PE = Pegamon-Elsevier, ES = Elsevier Science, $\mathrm{WB}=$ Wiley Blackwell, TF = Taylor \& Francis, SP = Springer, $\mathrm{SI}=$ SIAM Publications, $\mathrm{OX}=$ Oxford University Press, $\mathrm{KO}=$ Korean Inst. Electrical Eng., SA = Sage Publications, AS = ASME, MP = Microtome Publications [52].

\begin{tabular}{lllllllll}
\hline & IE & IT & PE & ES & WB TF & SP & SI & OX KO SA AS MP \\
\hline IEEEX & & & & & & & & \\
\hline ACM & & & & & \\
\hline Scopus & & & & & & \\
\hline WoS & & & & & & \\
\hline SD & & & & & & \\
\hline
\end{tabular}

Once the research questions have been identified and the relative Boolean function created, it must be introduced in the different bibliographic databases, adapting it according to the search language of each database. In this work, the research has been carried out by searching only in the abstract, title and keywords of the papers, obtaining a total of 3167 items until of November 2019, as detailed in Table 7. 
Table 7. Studies obtained by the chosen database.

\begin{tabular}{cc}
\hline Database & Studies \\
\hline IEEE Xplore & 842 \\
Web of Science & 590 \\
Scopus & 697 \\
ScienceDirect & 600 \\
ACM Digital Library & 17 \\
\hline & 3167 \\
\hline
\end{tabular}

A further, fundamental step of the Planning phase is the formulation of the inclusion and exclusion criteria. This criteria are very important, as they are used as objective rules for the selection of the studies that can become part of the review.

For a paper to become part of the review it must respect all the inclusion criteria, presented in Table 8 and must not contain any of the exclusion criteria presented in Table 9.

Table 8. Inclusion Criteria [1].

\begin{tabular}{cl}
\hline Num. & Description \\
\hline 1 & The technique should not be restricted to a particular machine (number of phases, etc) \\
\hline 2 & $\begin{array}{l}\text { Shall propose at least one detection technique (a parameter or an index that clearly and } \\
\text { uniquely identifies the failure or an automatic detection algorithm) }\end{array}$ \\
\hline 3 & $\begin{array}{l}\text { The technique shall have been tested at various operation points (different speed or } \\
\text { loads or a combination of both) }\end{array}$ \\
\hline 4 & $\begin{array}{l}\text { The technique shall not need special set-ups, configurations, loads or motor } \\
\text { manoeuvres }\end{array}$ \\
& $\begin{array}{l}\text { Characteristics of the detection and diagnosis algorithm: } \\
\text { a } \quad \begin{array}{l}\text { The paper shall demonstrate that the algorithm is capable to discern between } \\
\text { following cases: }\end{array} \\
\text { - Different levels of the same failure, demonstrating coherence (simulation or } \\
\text { test on real motor) } \\
\text { - On different real motors, demonstrating coherence }\end{array}$ \\
\end{tabular}

Table 9. Exclusion Criteria [1].

\begin{tabular}{cl}
\hline Num. & Description \\
\hline 1 & Grey literature and secondary studies \\
\hline 2 & Non English written papers \\
\hline 3 & Duplicated studies \\
\hline 4 & Full paper not available \\
\hline 5 & Lack of tests or simulations \\
\hline 6 & Use of big sensors, not embeddable in the motor \\
\hline 7 & Not focused on the selected topic \\
\hline
\end{tabular}


The inclusion criteria are all related to the research theme itself, i.e., they explain exactly what is expected to be found in an article in order to be accepted. Among the exclusion criteria, however, there are some points that are proper to the systematic review, such as the criterion that excludes all secondary studies or grey literature (books, book chapters, $\mathrm{PhD}$ thesis, reviews, etc.). In this way it is ensured that the selected articles have already passed through a peer-review process.

In addition to all these tools, needed to reduce the 3167 papers coming from the Boolean function search (see Table 7), it is needed to define some guidelines on how to carry out the selection of the studies and finally how to extract the data considered important from every paper.

The authors decided to extrapolate the following features from each article:

- Data of the article (e.g., author, year of publication, etc.)

- The type of failure

- The type of technique used

- The type of sensors used

- If it presents experiments or simulations

- If the algorithm has been tested at different speeds or loads

- If the algorithm has been tested in dynamic or stationary conditions

\section{Conducting}

The second phase of the SR is the conducting and is mainly divided into three parts: the selection of primary studies, a study quality assessment and finally the extraction and synthesis of data for each paper.

The main objectives of this phase are the following:

- to significantly reduce the large number of studies that have been obtained, by using the inclusion and exclusion criteria,

- to extract a features table in which the main characteristics of each article are highlighted.

\subsection{Selection of Primary Studies}

To guide the selection process of primary studies, it is very common to use the PRISMA [53] (Preferred Reporting Items for Systematic Reviews and Meta-Analyses) method. The method consists of 27 points and a flow chart built with the aim of making the whole process simpler and more ordered.

Referring to Figure 1, of the 3167 papers initially selected, the first screening takes place eliminating the duplicates, which in this case turn out to be 1217; this is due to the fact that many databases share some publishers, as shown in Table 6. It is advisable to use a software (Mendeley, Zotero, JabRef, etc.) to automatically detect the duplicates. Once the duplicates have been removed, it is necessary to take care of the grey literature as for some databases was not possible to exclude it during the research.

The following step has been to read the title, abstracts and keywords of the remaining 1950 papers, and to apply the inclusion and exclusion criteria to them.

Frequently, only by screening these particular fields, it is not possible to verify whether all the requirements have been met and, as a consequence, it is necessary to read the whole paper. This difficulty is principally due to the fact that generally, in the field of engineering, there is no normalisation of rules to create these fields, as they exist in other sectors such as medicine or psychology.

After this step, from the total amount of 1950 articles, 365 of them have been accepted for full paper review and finally, only 44 papers have met the selected criteria for being included in the revision. They will also be used to try to answer to all the questions previously formulated.

In conclusion, the papers that definitively became part of the review are 44 (see Figure 1), a much smaller amount if compared to the initial 1950, as shown in Figure 2.

The Conducting phase is certainly the most difficult phase and where perhaps more time has been spent compared to the whole systematic review, since 1950 papers have been carefully analysed. 
For many of these, the full-text review was necessary to verify and ascertain whether all the criteria had actually been met or not.

At this stage it's also where another reviewer comes in. As said there were two possibilities: either to revise all 1950 papers and then compare the results, or randomly choose some paper and review them to see if the SR has been carried out correctly.

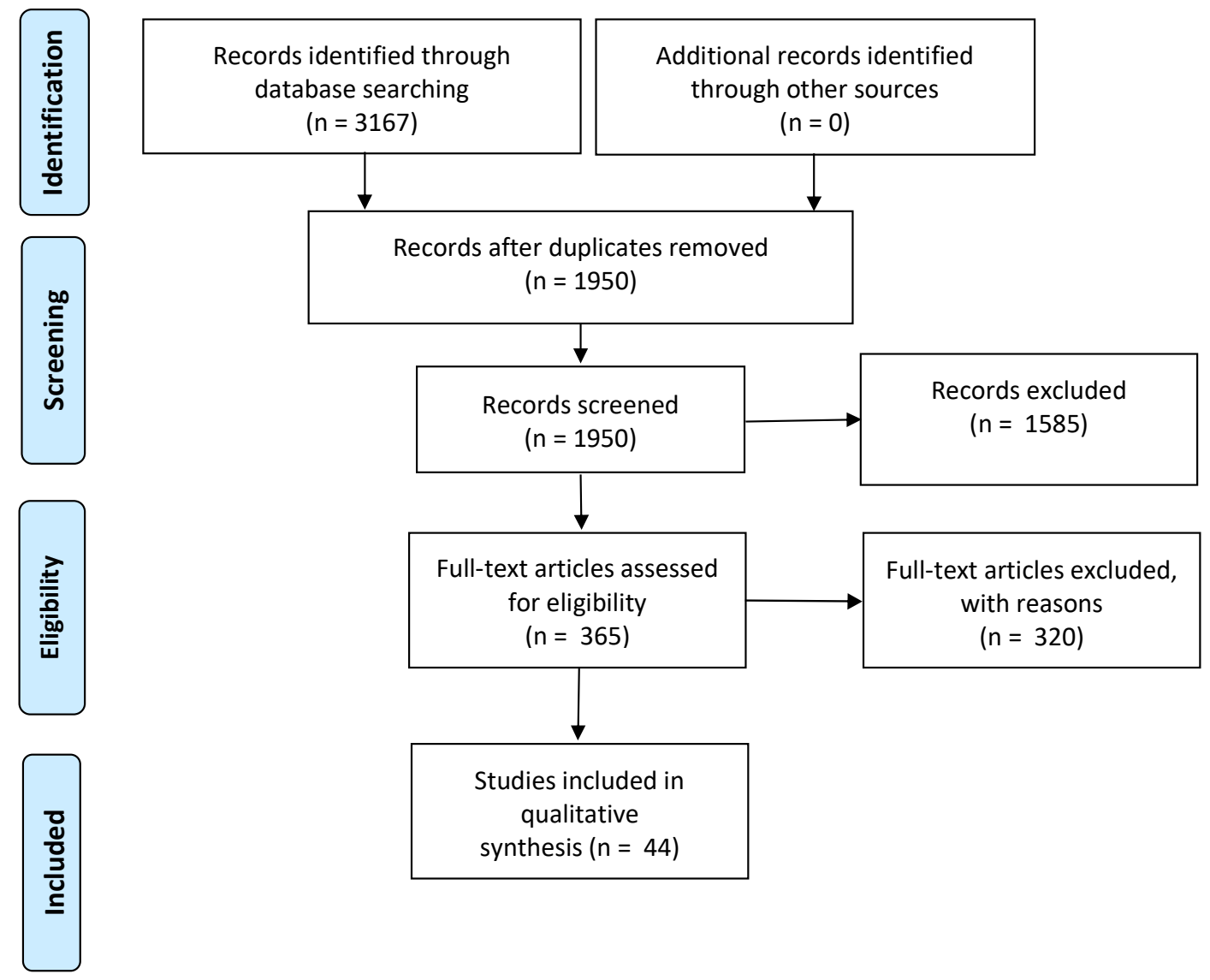

Figure 1. Preferred Reporting Items for Systematic Reviews and Meta-Analyses (PRISMA) flowchart [53].

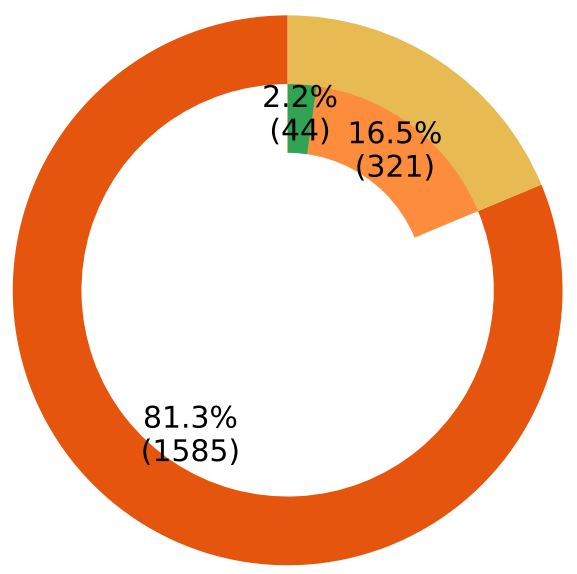

1st Screening - Rejected

Full Text Review

2nd Screening - Rejected

Accepted

Figure 2. Paper inclusion statistics

\subsection{Study Quality Assessment}

For the current systematic review 44 papers have been chosen. 
A quality study has been carried out on them, i.e., all the points presented in Table 10 have been analysed. The results of this quality assessment are shown in Table 11.

Table 10. Checklist for quality assessment

\begin{tabular}{llc}
\hline & Question & Score \\
\hline$Q_{1}$ & Is the problem presented clearly? & Yes/Partly/No \\
$Q_{2}$ & Is the methodology used presented clearly? & Yes/Partly/No \\
$Q_{3}$ & Is there a discussion of the results? & Yes/Partly/No \\
$Q_{4}$ & Does it answer to the presented problem(s)? & Yes/Partly/No \\
$Q_{5}$ & Number of cites & Cites \\
$Q_{6}$ & Where was it published? & Journal / Conference \\
\hline
\end{tabular}

Table 11. Checklist for quality assessment for the selected papers

\begin{tabular}{lcccccc}
\hline & $\mathrm{Q} 1$ & $\mathrm{Q} 2$ & $\mathrm{Q} 3$ & $\mathrm{Q} 4$ & $\mathrm{Q} 5$ & $\mathrm{Q6}$ \\
\hline$[9]$ & $\mathrm{Y}$ & $\mathrm{Y}$ & $\mathrm{P}$ & $\mathrm{Y}$ & 3 & Journal \\
{$[10]$} & $\mathrm{Y}$ & $\mathrm{P}$ & $\mathrm{Y}$ & $\mathrm{Y}$ & 12 & Journal \\
{$[11]$} & $\mathrm{Y}$ & $\mathrm{Y}$ & $\mathrm{Y}$ & $\mathrm{Y}$ & 5 & Journal \\
{$[12]$} & $\mathrm{Y}$ & $\mathrm{P}$ & $\mathrm{Y}$ & $\mathrm{P}$ & 1 & Journal \\
{$[1]$} & $\mathrm{Y}$ & $\mathrm{Y}$ & $\mathrm{Y}$ & $\mathrm{Y}$ & 3 & Journal \\
{$[13]$} & $\mathrm{Y}$ & $\mathrm{Y}$ & $\mathrm{P}$ & $\mathrm{P}$ & 1 & Journal \\
{$[14]$} & $\mathrm{Y}$ & $\mathrm{Y}$ & $\mathrm{Y}$ & $\mathrm{Y}$ & 2 & Conference \\
{$[15]$} & $\mathrm{P}$ & $\mathrm{Y}$ & $\mathrm{Y}$ & $\mathrm{P}$ & 1 & Conference \\
{$[16]$} & $\mathrm{Y}$ & $\mathrm{Y}$ & $\mathrm{Y}$ & $\mathrm{Y}$ & 1 & Journal \\
{$[17]$} & $\mathrm{Y}$ & $\mathrm{Y}$ & $\mathrm{P}$ & $\mathrm{P}$ & 0 & Conference \\
{$[18]$} & $\mathrm{Y}$ & $\mathrm{P}$ & $\mathrm{P}$ & $\mathrm{P}$ & 0 & Conference \\
{$[19]$} & $\mathrm{Y}$ & $\mathrm{P}$ & $\mathrm{Y}$ & $\mathrm{Y}$ & 1 & Conference \\
{$[20]$} & $\mathrm{Y}$ & $\mathrm{Y}$ & $\mathrm{Y}$ & $\mathrm{Y}$ & 13 & Journal \\
{$[21]$} & $\mathrm{Y}$ & $\mathrm{N}$ & $\mathrm{N}$ & $\mathrm{P}$ & 2 & Journal \\
{$[22]$} & $\mathrm{Y}$ & $\mathrm{Y}$ & $\mathrm{P}$ & $\mathrm{Y}$ & 1 & Conference \\
{$[23]$} & $\mathrm{Y}$ & $\mathrm{P}$ & $\mathrm{Y}$ & $\mathrm{Y}$ & 7 & Journal \\
{$[24]$} & $\mathrm{P}$ & $\mathrm{Y}$ & $\mathrm{P}$ & $\mathrm{Y}$ & 7 & Journal \\
{$[25]$} & $\mathrm{Y}$ & $\mathrm{P}$ & $\mathrm{P}$ & $\mathrm{Y}$ & 5 & Conference \\
{$[26]$} & $\mathrm{Y}$ & $\mathrm{Y}$ & $\mathrm{Y}$ & $\mathrm{Y}$ & 21 & Journal \\
{$[27]$} & $\mathrm{Y}$ & $\mathrm{P}$ & $\mathrm{Y}$ & $\mathrm{Y}$ & 18 & Journal \\
{$[28]$} & $\mathrm{Y}$ & $\mathrm{Y}$ & $\mathrm{Y}$ & $\mathrm{Y}$ & 15 & Journal \\
{$[29]$} & $\mathrm{Y}$ & $\mathrm{Y}$ & $\mathrm{Y}$ & $\mathrm{Y}$ & 5 & Journal \\
{$[30]$} & $\mathrm{Y}$ & $\mathrm{Y}$ & $\mathrm{P}$ & $\mathrm{Y}$ & 4 & Journal \\
{$[31]$} & $\mathrm{Y}$ & $\mathrm{Y}$ & $\mathrm{P}$ & $\mathrm{Y}$ & 5 & Conference \\
{$[32]$} & $\mathrm{Y}$ & $\mathrm{Y}$ & $\mathrm{P}$ & $\mathrm{P}$ & 3 & Conference \\
{$[33]$} & $\mathrm{Y}$ & $\mathrm{P}$ & $\mathrm{Y}$ & $\mathrm{P}$ & 30 & Journal \\
{$[34]$} & $\mathrm{P}$ & $\mathrm{N}$ & $\mathrm{Y}$ & $\mathrm{Y}$ & 20 & Journal \\
{$[35]$} & $\mathrm{Y}$ & $\mathrm{P}$ & $\mathrm{N}$ & $\mathrm{Y}$ & 19 & Conference \\
{$[36]$} & $\mathrm{Y}$ & $\mathrm{P}$ & $\mathrm{Y}$ & $\mathrm{Y}$ & 24 & Journal \\
{$[37]$} & $\mathrm{Y}$ & $\mathrm{P}$ & $\mathrm{P}$ & $\mathrm{P}$ & 70 & Journal \\
{$[38]$} & $\mathrm{Y}$ & $\mathrm{P}$ & $\mathrm{Y}$ & $\mathrm{Y}$ & 68 & Journal \\
{$[39]$} & $\mathrm{Y}$ & $\mathrm{P}$ & $\mathrm{P}$ & $\mathrm{Y}$ & 5 & Conference \\
{$[40]$} & $\mathrm{N}$ & $\mathrm{Y}$ & $\mathrm{Y}$ & $\mathrm{Y}$ & 38 & Journal \\
{$[41]$} & $\mathrm{Y}$ & $\mathrm{Y}$ & $\mathrm{Y}$ & $\mathrm{Y}$ & 45 & Journal \\
{$[42]$} & $\mathrm{Y}$ & $\mathrm{Y}$ & $\mathrm{Y}$ & $\mathrm{Y}$ & 35 & Journal \\
\hline & & & & & & \\
\hline
\end{tabular}


Table 11. Cont.

\begin{tabular}{ccccccc}
\hline & Q1 & Q2 & Q3 & Q4 & Q5 & Q6 \\
\hline$[43]$ & $\mathrm{Y}$ & $\mathrm{P}$ & $\mathrm{P}$ & $\mathrm{Y}$ & 6 & Conference \\
{$[44]$} & $\mathrm{Y}$ & $\mathrm{P}$ & $\mathrm{Y}$ & $\mathrm{Y}$ & 45 & Journal \\
{$[45]$} & $\mathrm{Y}$ & $\mathrm{P}$ & $\mathrm{Y}$ & $\mathrm{Y}$ & 84 & Journal \\
{$[46]$} & $\mathrm{Y}$ & $\mathrm{P}$ & $\mathrm{P}$ & $\mathrm{Y}$ & 14 & Conference \\
{$[47]$} & $\mathrm{P}$ & $\mathrm{P}$ & $\mathrm{P}$ & $\mathrm{P}$ & 3 & Conference \\
{$[48]$} & $\mathrm{P}$ & $\mathrm{P}$ & $\mathrm{P}$ & $\mathrm{P}$ & 13 & Conference \\
{$[49]$} & $\mathrm{P}$ & $\mathrm{P}$ & $\mathrm{P}$ & $\mathrm{P}$ & 10 & Conference \\
{$[50]$} & $\mathrm{P}$ & $\mathrm{Y}$ & $\mathrm{P}$ & $\mathrm{P}$ & 18 & Conference \\
{$[51]$} & $\mathrm{Y}$ & $\mathrm{Y}$ & $\mathrm{Y}$ & $\mathrm{Y}$ & 108 & Journal \\
\hline
\end{tabular}

Table 11 contains only qualitative information related to the selected articles. Some answers may be more or less objective, as for example if the problem or methodology have been presented clearly, while others are completely objective, as for example the cites of each article with respect to year of publication or if it has been published in a journal or in a conference.

\subsection{Extraction and Synthesis Of Data}

In order to extract and synthesise the data of the selected papers, a summary table (Tables 1-4) has been created. It has to be pointed out that the data presented in this work is updated to November 2019. In this tables are listed the more important characteristics of the papers related to the research topic.

- Year of publication;

- The category of the detected fault. This field can be one or more of the following items: armature faults, mechanical faults or permanent magnet faults;

- The class of the technique used for the detection. The main categories have been selected to be:

- Radio-frequency emissions monitoring,

- Electromagnetic field monitoring,

- Infrared recognition,

- Noise and vibration monitoring,

- Model, AI, and neural-network-based techniques,

- Temperature measurements,

- Chemical analysis,

- Acoustic noise measurements,

- Parameters estimation,

- MCSA,

- Other (specify).

The last item has been left if some technique cannot be classified into the previously listed categories;

- The sensor(s) needed for the failure detection technique implementation;

- If the demonstration of the effectiveness of the proposed detection techniques has been carried out with simulations and/or experiments;

- If the simulations and/or experiments have been carried out under different working conditions, such as different speeds and/or different loads;

- If the proposed technique is capable of working during changes in load and/or speed or the working conditions should be kept stationary;

- Other limitations and/or advantages. This feature is the only one that is subjective, but it contains useful information that cannot be collected in the other features.

The papers are presented in chronological order. This is usually done when performing a systematic review to put in evidence the major number of articles on the topic published during the last years. It is also useful to show if there is some clear change in research trend about one of the considered parameters. 


\section{Reporting}

The SR is completed here by carrying out the reporting, i.e., a discussion about the obtained results. Additionally, a detailed answers to each of the research questions previously formulated and general considerations about the techniques are provided.

\subsection{Discussion}

This section will present some statistical data about the study and the present review and, more in general, about the chosen topic. Figure 3 shows this trend by representing the number of papers per year published on this thematic (results from 1990 to 2018) emerged from the research after that the first screening has been passed (year 2019 was not included in Figure 3, because it was not considered the whole year). This is a clear sign that research community is highly interested in the topic and this interest is growing very fast during the last years.

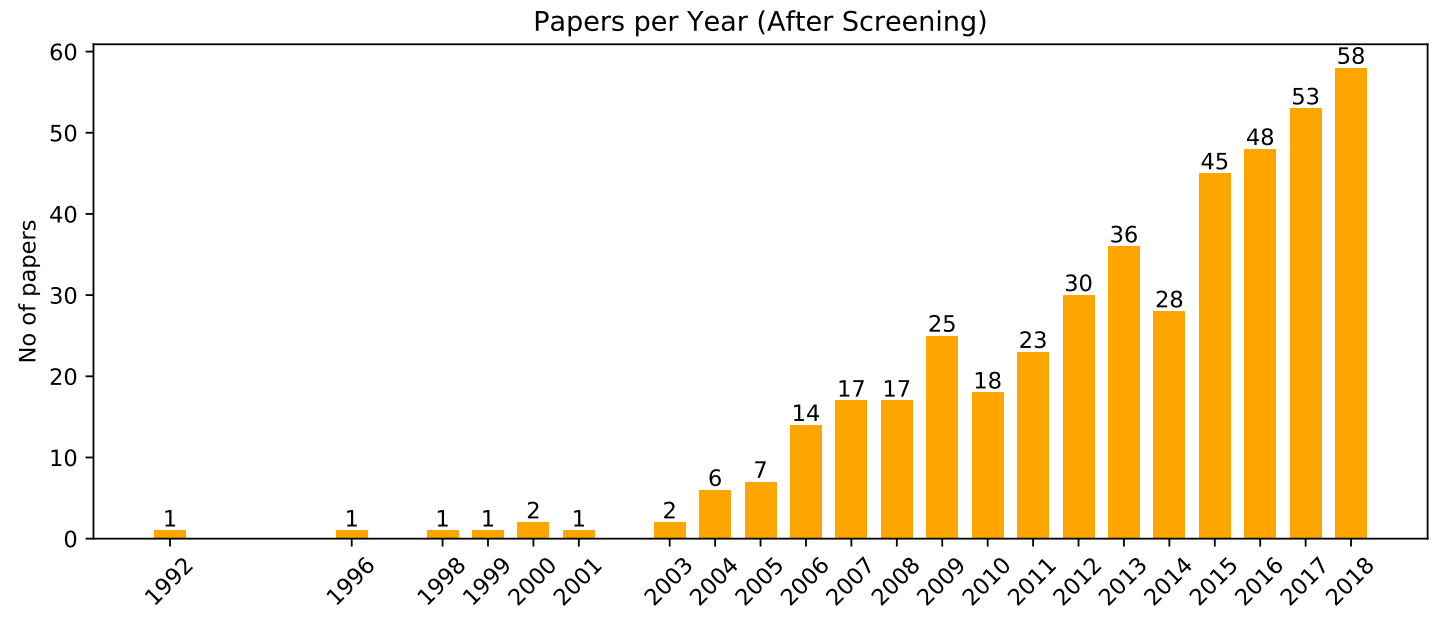

Figure 3. Papers on the topic, after the first screening of title and abstract and keywords.

This tendency is perhaps due to the current impulse in developing high reliability aircraft and electric vehicles, and similarly to the recent availability of new techniques and more powerful processors which promoted innovative applications [1]. In this view, it is useful to analyse how the number of articles based on certain techniques are distributed over the year of publication (Figure 4).

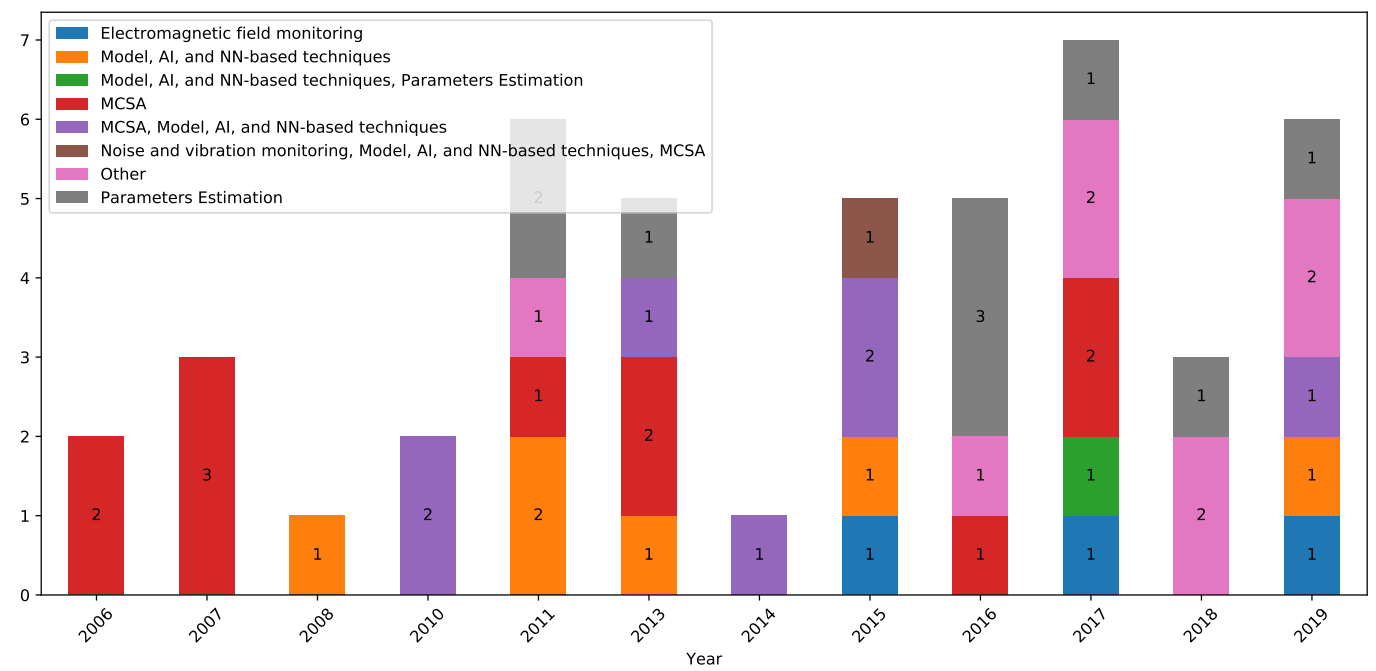

Figure 4. Distribution of the used techniques over the publication year. 
Figure 4 is not representative of the whole literature, but it is possible to use it to investigate the progresses on the topic. During the last years, the techniques based on artificial intelligence, parameters estimation and models, are being utilised with increasing frequency, often as classifiers, in conjunction with established methods like the MCSA. On the other hand, the number of articles presenting detection techniques based on MCSA has drastically reduced, probably because these techniques have been intensively studied in the past years and there is less space left for innovations. Starting from 2016 techniques tagged with Other, i.e., the techniques not classifiable in the previously defined categories, have steadily increased in number. This indicates that previously unexplored phenomena are being used for BLDC fault detection and outlines that the research on the chosen topic is in turmoil.

Figure 5 shows the overall distribution of the papers according to the used technique. The following techniques have been omitted from the graph because they have not been found:

- radio-frequency emissions monitoring,

- temperature measurements,

- infrared recognition,

- chemical analysis.

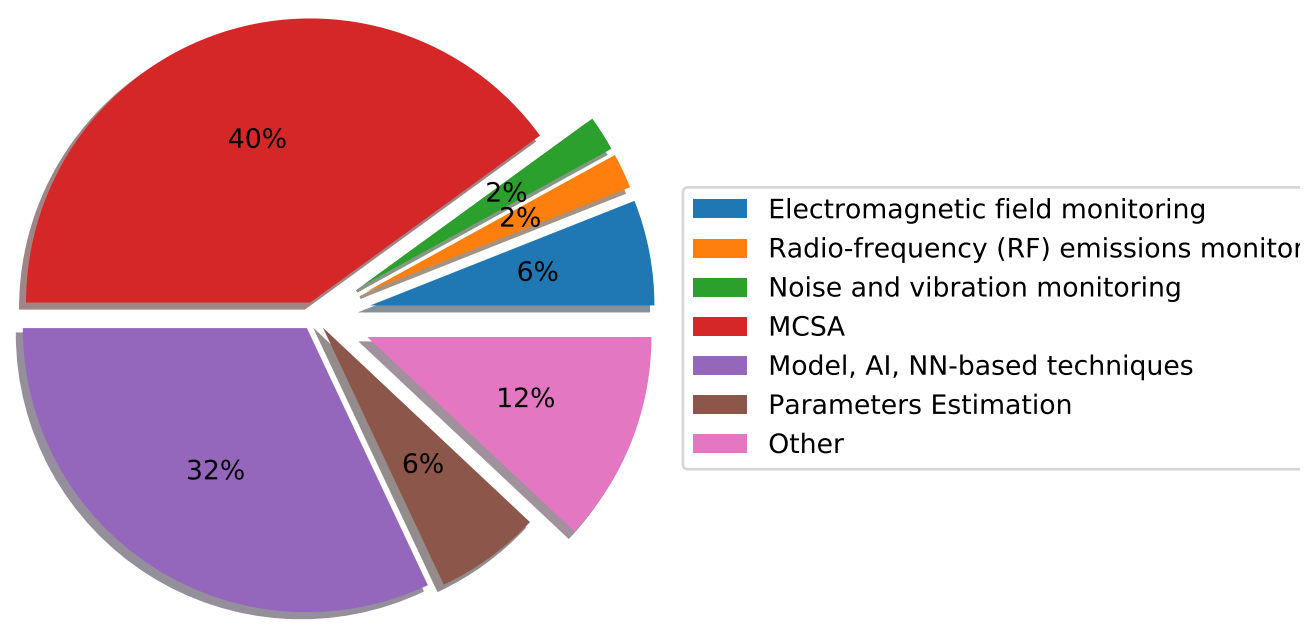

Figure 5. Distribution articles according to the used techniques

The MCSA is the most used technique, followed by the AI algorithms. It is important to point out that frequently the techniques based on Artificial Intelligence are used as classifiers of results obtained with other, already established, methods for failure detection. This association demonstrated to be have a great impact in improving the detection rate and in extending the use of the technique for a wider range of both speed and load.

One other key aspect in the graph, is the presence of a good amount of papers using techniques which were not previously classified (grouped under the tag other). Between them it is possible to find innovative techniques based on High Frequency Injection [41], hall effect sensors measurements [22] or innovative motor signals analysis $[1,14,15]$.

An interesting alternative for the techniques based on Electromagnetic field monitoring is represented by [13]. The authors use external sensor to sense the stray magnetic fields outside the stator to detect armature failures severity and location, solving one of the biggest drawback of this powerful techniques category, i.e., the invasive procedure of placing additional windings inside the stator core.

The next paragraphs are dedicated to answer to the previously formulated research questions by using the selected papers. 


\subsubsection{Rq.1: Most Common Failures of Bldc Motors}

Figure 6 shows the distribution of the papers in relation to the type of failure discussed. The results are in accordance with the failure distribution presented in various papers $[29,31,36,54]$, and, in turn, this means that the research efforts are consistent with the failures occurrence.

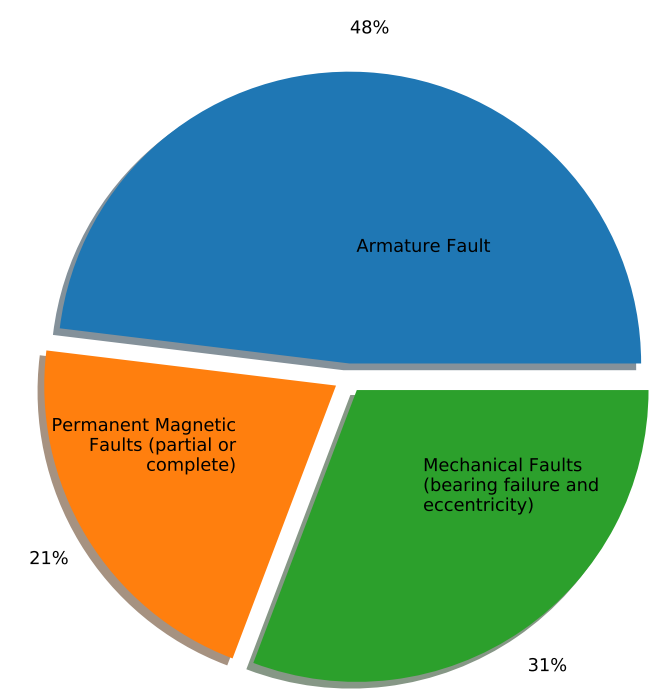

Figure 6. Distribution of the papers according the type of failure

\subsubsection{Rq.2: Parameters Used for Failure Detection in Bldc Motors}

Due to the intense research in this field, many of the motor parameters have been used for fault detection purposes. In the following, the variables used will be listed, dividing them between those directly measurable and those estimated.

\section{Directly measurable quantities}

The quantities listed below are directly measurable by using specific sensors.

Output torque Torque-meters shall be used to measure this variable and it can provide very useful information. The problem resides in the fact that this type of sensors are often big and expensive.

Current The current is always already measured by the motor controller and there are an immense quantity of failure detection algorithms based on this variable.

Voltage The voltage is also commonly measured by the motor controller.

Vibrations By placing accelerometers on the motor, it is possible to measure its vibration level. The algorithms based on vibration analysis could present problems when used in moving systems, like aircraft, due to the coupling of external and unpredictable vibrations.

Magnetic flux The magnetic flux gives a deep insight on how the motor is working. In order to measure it, it is usually necessary to include in the motor winding so called search coils, i.e., some additional windings not connected to the phases. The inclusion of these additional coils is not common and, although being a simple procedure, it need to unmount the motor, rewound it and to extract from the interior as many pairs of wires as many search coils as are inserted. An alternative to this procedure is to place external magnetic sensors on the stator to sense the stray magnetic fields.

\section{Estimated quantities}

The procedures based on parameters estimation can identify failures by evaluating the changes within the measured motor parameters as well as evaluating factors which are not straightforwardly quantifiable, such as: 
- $\quad$ Back-EMF,

- Magnetic flux,

- Winding resistance,

- Winding inductance.

Estimation could be a effective instrument which allows the use of variables straightforwardly related to the fault and something else not measurable. The drawback is that it depends on models which can be constrained to particular working points and affected by the shift of some parameter.

\subsubsection{Rq.3: Type of Failures Detectable by Each Technique}

Figure 7 represents the distribution of the different papers according to the various techniques proposed for detecting different types of faults. This allows to evaluate which techniques are most suitable for detecting and distinguishing between different types of failure or if some techniques are more suitable for detecting specific faults or can be used as a broad spectrum analysis tool.

The techniques are widely distributed among the types detection methods, with the exception of vibration monitoring which appears limited to the detection of mechanical faults; however, this specific item can be biased due to the presence of only one single paper in the review for this category.

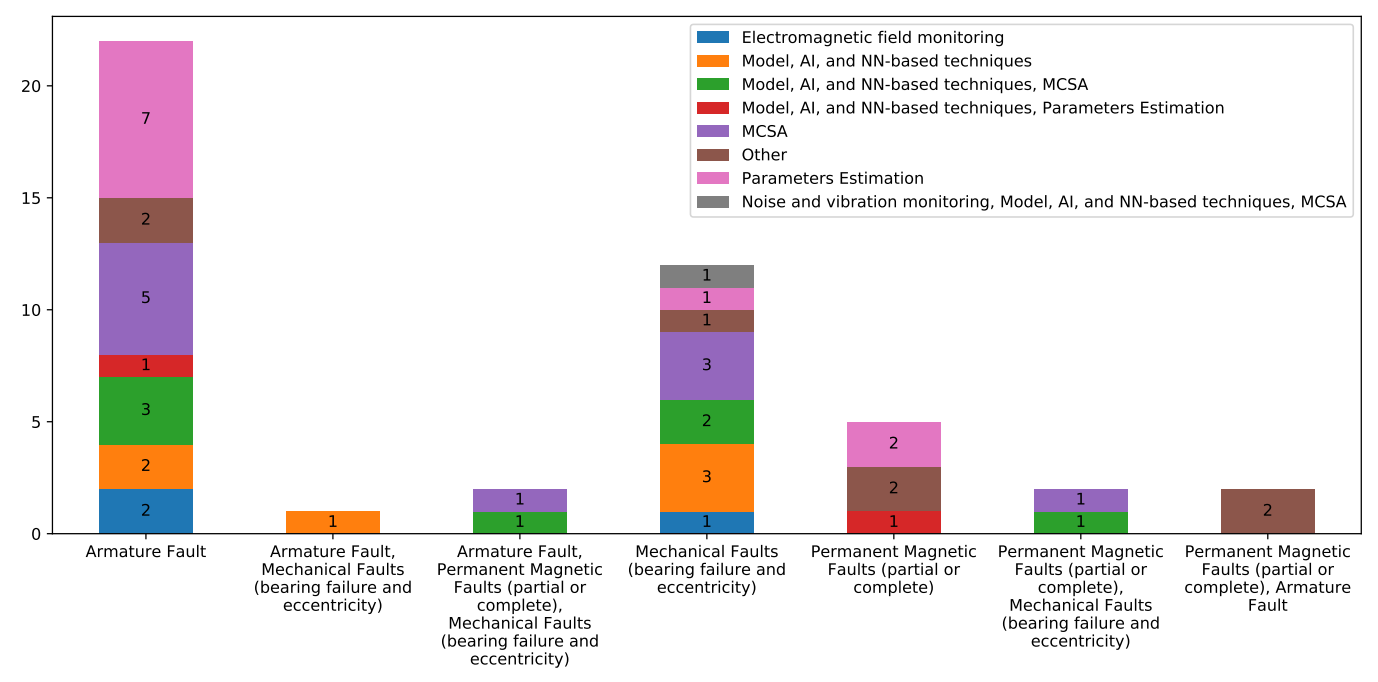

Figure 7. Distribution of the papers according the type of failure and the used technique.

\subsubsection{Rq.4: Computational Power Needed for Each Technique}

Only a few papers $([18,19,55])$ offered a clear quantification of the computational power needed to implement the proposed technique, and therefore this question can only be answered in a qualitative manner. By what has emerged it can be seen that by a theoretical point of view the most costly strategies are those focused on models. That is because of the necessity of running the computer model parallel to the machine itself when comparing the outputs.

In addition, the complexity increases with the level of detail of the model, the parameters involved, etc. The following techniques in terms of computational cost are those based on the estimation of the parameter and then those that use the NNs. In any case, it mostly depends on the way the algorithms are implemented. The least expensive techniques are the MCSA and other techniques which directly analyse sensor data.

\subsubsection{Rq.5: Sensors Needed for Each Technique}

Generally the techniques that require less sensors are based on current or voltage analysis, such as MCSA. The near-totality of the reviewed methods must at least measure current consumption and motor voltage, although this is not an issue as these quantities are already available in most drivers. 
Many methods also employ the motor speed to diagnose the fault. It can be speed can be estimated, from back-EMF measurements, or obtained directly from Hall effect frequency sensors or from a resolver [1].

\subsubsection{Rq.6: Best Detection Results}

Only some selected papers ([10,11,18,19,26,29-31,35,43,45]) provide statistics on the rate of error detection and are mostly based on the use of AI. It is very complex to compare all these results, since the test conditions are not uniform.

This is considered a weak point in this topic, which, although being very rich in ideas and proposed techniques, lacks validation and verification of the same. A possible solution to this problem, would be to propose a minimum standard set of tests to be performed in order to validate a fault detection algorithm and generate a set of minimum comparable outcomes [1].

\subsection{General Considerations About The Techniques}

In Table 12 the main characteristics of the detection methods have been grouped. As previously mentioned, the techniques based on AI are very effective. These can be used either as stand-alone fault detectors or in combination with other techniques to significantly improve their performance in detection. It must be noted, in any case, that their success relies on an intense process of learning and they take considerable time before working properly [1].

Referring to the statistics listed above, in particular Figure 4, it is possible to notice how fault detection techniques based on parameter estimation have also seen an increase in number.

Such techniques can provide continuous access to otherwise unobservable variables such as back-EMF or magnetic flux, facilitate the task of fault detection or identify more explicitly observable fault indicators. Noteworthy is their characteristic of being able of working while the motor is running in non-steady-state conditions of speed and/or torque. On the other hand, the potential problem with these techniques is that they are based on assumptions, models and measurements of motor variables whose limited validity and inaccuracy could hinder fault detection. According to the results of this research, about one third of the selected articles propose a technique able to work in non-stationary conditions and most of them are based on AI, NN and parameters estimation.

The need to operate the motor under steady-state conditions can be a significant limitation, above all if this is necessary to measure signals over a long period of time. Such condition may be achieved with large industrial machines working at constant load but rarely in aircraft actuators [1].

Table 12. Techniques summary [1].

\begin{tabular}{|c|c|c|c|c|c|}
\hline & $\begin{array}{l}\text { Noise and Vibration } \\
\text { Monitoring }\end{array}$ & $\begin{array}{l}\text { Electromagnetic } \\
\text { Field Monitoring }\end{array}$ & $\begin{array}{l}\text { Motor Current } \\
\text { Signature Analysis }\end{array}$ & $\begin{array}{l}\text { Model and AI based } \\
\text { techniques }\end{array}$ & $\begin{array}{l}\text { Parameters } \\
\text { Estimation }\end{array}$ \\
\hline Advantages & $\begin{array}{l}\text { Most suitable method } \\
\text { for detecting } \\
\text { mechanical faults, } \\
\text { as the accelerometers } \\
\text { can be placed close to } \\
\text { the vibration source }\end{array}$ & $\begin{array}{l}\text { Can directly measure } \\
\text { the electromagnetic } \\
\text { field inside the motor, } \\
\text { does not need } \\
\text { complicated } \\
\text { algorithm to detect } \\
\text { failures, can virtually } \\
\text { detect all the } \\
\text { motor failures }\end{array}$ & $\begin{array}{l}\text { Does not need } \\
\text { additional sensors, } \\
\text { can detect a large } \\
\text { variety of failures, is } \\
\text { the most used } \\
\text { technique }\end{array}$ & $\begin{array}{l}\text { Can be used during } \\
\text { non-stationary motor } \\
\text { operation, can be } \\
\text { used in conjunction } \\
\text { with other techniques }\end{array}$ & $\begin{array}{l}\text { Can be used during } \\
\text { non-stationary motor } \\
\text { operation, can } \\
\text { virtually monitor } \\
\text { every } \\
\text { motor parameter }\end{array}$ \\
\hline Disadvantage & $\begin{array}{l}\text { Need to install } \\
\text { accelerometers on the } \\
\text { motor, measurements } \\
\text { can be corrupted by } \\
\text { environmental } \\
\text { vibrations, difficult to } \\
\text { use in non-stationary } \\
\text { motor operation }\end{array}$ & $\begin{array}{l}\text { Need to rewind the } \\
\text { stator and to extract } \\
\text { as many additional } \\
\text { cables as many } \\
\text { coils inserted }\end{array}$ & $\begin{array}{l}\text { Need to transform } \\
\text { the signal in the } \\
\text { frequency domain, } \\
\text { the motor current } \\
\text { depend on the load, } \\
\text { cannot be used } \\
\text { during } \\
\text { non-stationary } \\
\text { motor operation }\end{array}$ & $\begin{array}{l}\text { Need extensive } \\
\text { training }\end{array}$ & $\begin{array}{l}\text { The method depends } \\
\text { on the knowledge of } \\
\text { various motor } \\
\text { parameters and on } \\
\text { the accuracy of the } \\
\text { model, their variation } \\
\text { (or incorrectness) can } \\
\text { result in poor } \\
\text { diagnosis performance }\end{array}$ \\
\hline
\end{tabular}




\section{Conclusions}

This paper presents a systematic review of high TRL techniques for BLDC motors failures detection, that have been published in the period of time from the early 1990s to November 2019. In addition, the article itself can be considered as a proof of concept of applying the SR to a particular study case in the aerospace field, in order to demonstrate its feasibility.

The studies presented in this work, have been analysed to respond to the research questions posed, that is, what are the techniques applied for fault detection, the sensors used, the working condition, what are their advantages and limitations. These results have been included in multiple tables to illustrate the findings and ease the consultation.

The greatest difficulty encountered during this study has been the impossibility of comparing the the different proposed algorithms in terms of performance, due to the lack of uniformity in tests, features measurement and estimation and presentation of the results. The authors would suggest, as a possible solution to this issue, a study to introduce a standardised benchmark and a set of parameters to be presented in order to harmonise the evaluation of the fault detection algorithms.

Author Contributions: Conceptualisation, V.M.F.; Funding acquisition, M.Á.M.P.; Investigation, V.M.F. and C.I.; Methodology, V.M.F. and C.I.; Supervision, M.Á.M.P.; Validation, C.I.; Writing-original draft, V.M.F.; Writing-review \& editing, V.M.F. and C.I. All authors have read and agreed to the published version of the manuscript.

Funding: The research leading to these results has been partly funded by the European Research Council under the European Union's Seventh Framework Programme (FP7/2007-2013)/ ERC grant agreement n. 785332

Conflicts of Interest: The authors declare no conflict of interest.

\section{Abbreviations}

The following abbreviations are used in this manuscript:

$\begin{array}{ll}\text { AI } & \text { Artificial Intelligence } \\ \text { BLDC } & \text { Brushless Direct Current } \\ \text { FEM } & \text { Finite Element Method } \\ \text { HF } & \text { High Frequency } \\ \text { MCSA } & \text { Motor Current Signature Analysis } \\ \text { NN } & \text { Neural Network } \\ \text { SR } & \text { Systematic Review } \\ \text { SVM } & \text { Support Vector Machine } \\ \text { TRL } & \text { Technology Readiness Level }\end{array}$

\section{Appendix A Nomenclature}

By going through the literature, the terminology in this field appears non-uniform. This is due to the fact that fault detection and diagnosis is usually distributed over many different disciplines. The definition of the following terms is specified in the glossary section and is based on $[1,56]$. This terminology will be used along the entire document.

Fault : Unpermitted deviation of at least one feature (characteristic property) of the system out of the acceptable standard condition threshold. The fault is a state of the system and can be of various types (manufacturing, assembly, maintenance, software, operators, wrong operation). It may not affect the correct functioning of the overall system

Failure : Permanent interruption of a system's ability to perform a required function under determined operating conditions.

Malfunction : Intermittent irregularity in the fulfilment of a system's function. It can arise from one or more faults.

From the description it is possible to draw the relationship between faults, failures and malfunctions (Figure A1). 


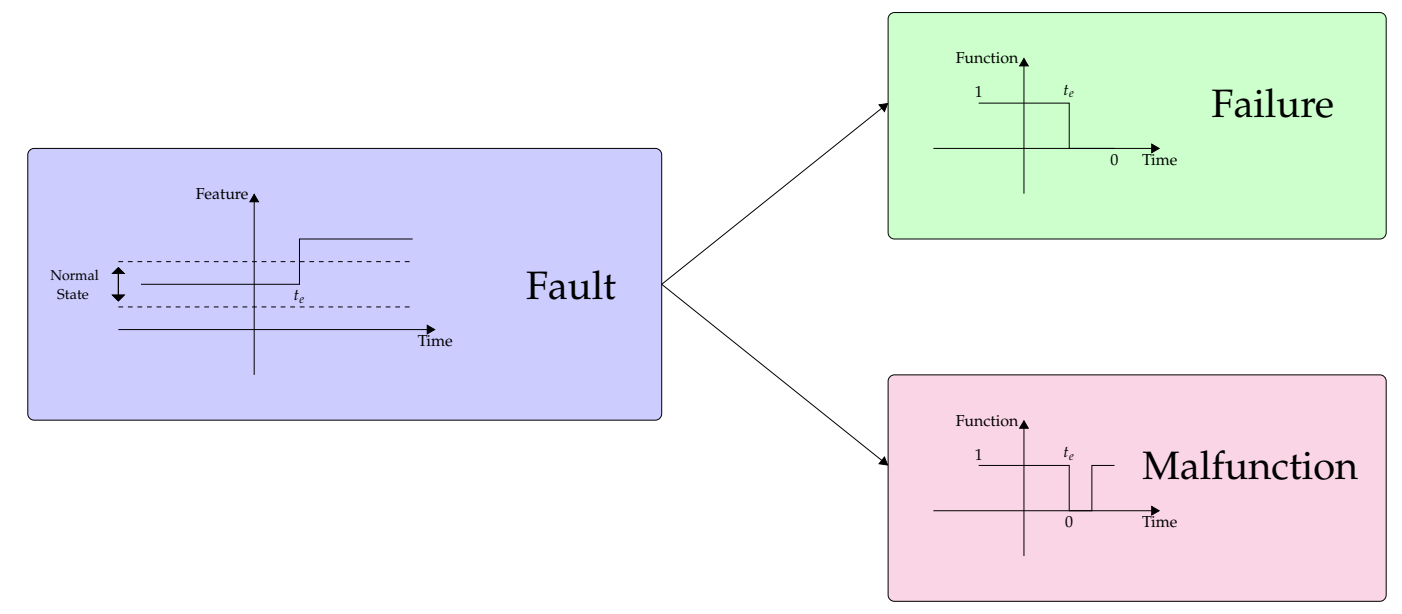

Figure A1. Scheme of the relation between faults, failures and malfunctions [1].

\section{References}

1. Fico, V.M.; Vázquez, A.L.R.; Prats, M.Á.M.; Bernelli-Zazzera, F. Failure detection by signal similarity measurement of brushless DC motors. Energies 2019, 12. [CrossRef]

2. Basak, D.; Tiwari, A.; Das, S.P. Fault diagnosis and condition monitoring of electrical machines-A review. In Proceedings of the IEEE International Conference on Industrial Technology, Mumbai, India, 15-17 December 2006; pp. 3061-3066. [CrossRef]

3. Buchwald, H.; Avidor, Y.; Braunwald, E.; Jensen, M.D.; Pories, W.; Fahrbach, K.; Schoelles, K. Bariatric surgery: A systematic review and meta-analysis. JAMA 2004, 292, 1724-1737. [CrossRef] [PubMed]

4. Renehan, A.G.; Tyson, M.; Egger, M.; Heller, R.F.; Zwahlen, M. Body-mass index and incidence of cancer: A systematic review and meta-analysis of prospective observational studies. Lancet 2008, 371, 569-578. [CrossRef]

5. Kitchenham, B.; Charters, S. Guidelines for performing systematic literature reviews in software engineering. In EBSE Technical Report; Elsevier: Amsterdam, The Netherlands, 2007; pp. 1-65.

6. Hall, T.; Beecham, S.; Bowes, D.; Gray, D.; Counsell, S. A systematic literature review on fault prediction performance in software engineering. IEEE Trans. Softw. Eng. 2011, 38, 1276-1304. [CrossRef]

7. Kitchenham, B.; Brereton, O.P.; Budgen, D.; Turner, M.; Bailey, J.; Linkman, S. Systematic literature reviews in software engineering-A systematic literature review. Inf. Softw. Technol. 2009, 51, 7-15. [CrossRef]

8. Ierardi, C.; Orihuela, L.; Jurado, I. Distributed Estimation Techniques for Cyber-Physical Systems: A Systematic Review. Sensors 2019, 19, 4720. [CrossRef]

9. Ge, Y.; Song, B.; Pei, Y.; Mollet, Y.A.; Gyselinck, J.J. Analytical Expressions of Isolation Indicators for Permanent-Magnet Synchronous Machines Under Stator Short-Circuit Faults. IEEE Trans. Energy Convers. 2019, 34, 984-992. [CrossRef]

10. Kao, I.H.; Wang, W.J.; Lai, Y.H.; Perng, J.W. Analysis of Permanent Magnet Synchronous Motor Fault Diagnosis Based on Learning. IEEE Trans. Instrum. Meas. 2019, 68, 310-324. [CrossRef]

11. Heydarzadeh, M.; Zafarani, M.; Nourani, M.; Akin, B. A Wavelet-Based Fault Diagnosis Approach for Permanent Magnet Synchronous Motors. IEEE Trans. Energy Convers. 2019, 34, 761-772. [CrossRef]

12. Zandi, O.; Poshtan, J. Fault Diagnosis of Brushless DC Motors Using Built-In Hall Sensors. IEEE Sensors J. 2019, 19, 8183-8190. [CrossRef]

13. Liu, X.; Miao, W.; Xu, Q.; Cao, L.; Liu, C.; Pong, P.W.T. Inter-Turn Short-Circuit Fault Detection Approach for Permanent Magnet Synchronous Machines Through Stray Magnetic Field Sensing. IEEE Sens. J. $2019,1$. [CrossRef]

14. Ye, M.; Huang, J. Bearing Fault Diagnosis under Time-Varying Speed and Load Conditions via Speed Sensorless Algorithm and Angular Resample. In Proceedings of the 2018 23rd International Conference on Electrical Machines (ICEM 2018), Alexandroupoli, Greece, 3-6 September 2018; pp. 1775-1781. [CrossRef] 
15. Ullah, Z.; Lee, S.; Hur, J. A Novel Fault Diagnosis Technique for IPMSM Using Voltage Angle. In Proceedings of the 2018 IEEE Energy Conversion Congress and Exposition (ECCE), Portland, OR, USA, 23-27 September 2018; pp. 3236-3243. [CrossRef]

16. Moon, S.; Jeong, H.; Lee, H.; Kim, S.W. Interturn Short Fault Diagnosis in a PMSM by Voltage and Current Residual Analysis With the Faulty Winding Model. IEEE Trans. Energy Convers. 2018, 33, 190-198. [CrossRef]

17. Ahsanullah, K.; Jeyasankar, E.; Vignesh, A.; Panda, S.; Shanmukha, R.; Nadarajan, S. Eccentricity fault analysis in PMSM based marine propulsion motors. In Proceedings of the 20th International Conference on Electrical Machines and Systems, Sydney, NSW, Australia, 11-14 August 2017; pp. 1-6.

18. Breuneval, R.; Clerc, G.; Nahid-Mobarakeh, B.; Mansouri, B. Hybrid diagnosis of intern-turn short-circuit for aircraft applications using SVM-MBF. In Proceedings of the 2017 IEEE International Conference on Fuzzy Systems (FUZZ-IEEE), Cincinnati, OH, USA, 1-5 October 2017; pp. 1-6.

19. Heydarzadeh, M.; Zafarani, M.; Ugur, E.; Akin, B.; Nourani, M. A model-based signal processing method for fault diagnosis in PMSM machine. In Proceedings of the Energy Conversion Congress and Exposition (ECCE), Naples, Italy, 9-12 July 2017; pp. 3160-3164.

20. Mazzoletti, M.A.; Bossio, G.R.; De Angelo, C.H.; Espinoza-Trejo, D.R. A model-based strategy for interturn short-circuit fault diagnosis in PMSM. IEEE Trans. Ind. Electron. 2017, 64, 7218-7228. [CrossRef]

21. Obeid, N.H.; Battiston, A.; Boileau, T.; Nahid-Mobarakeh, B. Early Intermittent Interturn Fault Detection and Localization for a Permanent Magnet Synchronous Motor of Electrical Vehicles Using Wavelet Transform. IEEE Trans. Transp. Electrif. 2017, 3, 694-702. [CrossRef]

22. Park, Y.; Fernandez, D.; Lee, S.B.; Hyun, D.; Jeong, M.; Kommuri, S.K.; Cho, C.; Reigosa, D.; Briz, F. On-line detection of rotor eccentricity for PMSMs based on hall-effect field sensor measurements. In Proceedings of the Energy Conversion Congress and Exposition (ECCE), Cincinnati, OH, USA, 1-5 October 2017; pp. 4678-4685.

23. Zhu, M.; Hu, W.; Kar, N.C. Torque-ripple-based interior permanent-magnet synchronous machine rotor demagnetization fault detection and current regulation. IEEE Trans. Ind. Appl. 2017, 53, 2795-2804. [CrossRef]

24. Gu, B.G. Study of IPMSM interturn faults part II: Online fault parameter estimation. IEEE Trans. Power Electron. 2016, 31, 7214-7223. [CrossRef]

25. Jeong, H.; Moon, S.; Lee, J.; Kim, S.W. Inter-turn short fault diagnosis of permanent magnet synchronous machines using negative sequence components. In Proceedings of the 2016 IEEE International Conference on Industrial Technology (ICIT), Taipei, Taiwan, 14-17 March 2016; pp. 170-174.

26. Mbo'o, C.P.; Hameyer, K. Fault diagnosis of bearing damage by means of the linear discriminant analysis of stator current features from the frequency selection. IEEE Trans. Ind. Appl. 2016, 52, 3861-3868. [CrossRef]

27. Moon, S.; Lee, J.; Jeong, H.; Kim, S.W. Demagnetization fault diagnosis of a PMSM based on structure analysis of motor inductance. IEEE Trans. Ind. Electron. 2016, 63, 3795-3803. [CrossRef]

28. Sen, B.; Wang, J. Stator interturn fault detection in permanent-magnet machines using PWM ripple current measurement. IEEE Trans. Ind. Electron. 2016, 63, 3148-3157. [CrossRef]

29. Abed, W.; Sharma, S.; Sutton, R.; Motwani, A. A robust bearing fault detection and diagnosis technique for brushless DC motors under non-stationary operating conditions. Control. Autom. Electr. Syst. 2015, 26, 241-254. [CrossRef]

30. Akar, M.; Hekim, M.; Orhan, U. Mechanical fault detection in permanent magnet synchronous motors using equal width discretization-based probability distribution and a neural network model. Electr. Eng. Comput. Sci. 2015, 23, 813-823. [CrossRef]

31. Çira, F.; Arkan, M.; Gümüş, B. A new approach to detect stator fault in permanent magnet synchronous motors. In Proceedings of the 2015 IEEE 10th International Symposium on Diagnostics for Electrical Machines, Power Electronics and Drives (SDEMPED), Guarda, Portugal, 1-4 September 2015; pp. 316-321.

32. Lee, S.T.; Kim, K.T.; Hur, J. Diagnosis technique for stator winding inter-turn fault in BLDC motor using detection coil. In Proceedings of the 2015 9th International Conference on Power Electronics and ECCE Asia (ICPE-ECCE Asia), Seoul, Korea, 1-5 June 2015; pp. 2925-2931.

33. Moosavi, S.; Djerdir, A.; Ait-Amirat, Y.; Khaburi, D. ANN based fault diagnosis of permanent magnet synchronous motor under stator winding shorted turn. Electr. Power Syst. Res. 2015, 125, 67-82. [CrossRef]

34. Chakraborty, S.; Keller, E.; Ray, A.; Mayer, J. Detection and estimation of demagnetization faults in permanent magnet synchronous motors. Electr. Power Syst. Res. 2013, 96, 225-236. [CrossRef] 
35. Haddad, R.Z.; Strangas, E.G. Fault detection and classification in permanent magnet synchronous machines using Fast Fourier Transform and Linear Discriminant Analysis. In Proceedings of the 2013 9th IEEE International Symposium on Diagnostics for Electric Machines, Power Electronics and Drives (SDEMPED), Valencia, Spain, 27-30 August 2013; pp. 99-104.

36. Nyanteh, Y.D.; Srivastava, S.K.; Edrington, C.S.; Cartes, D.A. Application of artificial intelligence to stator winding fault diagnosis in Permanent Magnet Synchronous Machines. Electr. Power Syst. Res. 2013, 103, 201-213. [CrossRef]

37. Sarikhani, A.; Mohammed, O.A. Inter-turn fault detection in PM synchronous machines by physics-based back electromotive force estimation. IEEE Trans. Ind. Electron. 2013, 60, 3472-3484. [CrossRef]

38. Urresty, J.C.; Riba, J.R.; Romeral, L. Diagnosis of interturn faults in PMSMs operating under nonstationary conditions by applying order tracking filtering. IEEE Trans. Power Electron. 2013, 28, 507-515. [CrossRef]

39. Abu-Rub, H.; Ahmed, S.M.; Iqbal, A.; Toliyat, H.A.; Rahimian, M.M. Incipient bearing fault detection for three-phase Brushless DC motor drive using ANFIS. In Proceedings of the IEEE International Symposium on Diagnostics for Electric Machines, Power Electronics \& Drives, Bologna, Italy, 5-8 September 2011; pp. 620-625.

40. Leboeuf, N.; Boileau, T.; Nahid-Mobarakeh, B.; Clerc, G.; Meibody-Tabar, F. Real-time detection of interturn faults in PM drives using back-EMF estimation and residual analysis. IEEE Trans. Ind. Appl. 2011, 47, 2402-2412. [CrossRef]

41. Arellano-Padilla, J.; Sumner, M.; Gerada, C. Winding condition monitoring scheme for a permanent magnet machine using high-frequency injection. IET Electr. Power Appl. 2011, 5, 89-99. [CrossRef]

42. Kim, K.H.; Gu, B.G.; Jung, I.S. Online fault-detecting scheme of an inverter-fed permanent magnet synchronous motor under stator winding shorted turn and inverter switch open. IET Electr. Power Appl. 2011, 5, 529-539. [CrossRef]

43. Ondel, O.; Boutleux, E.; Clerc, G. Diagnosis by pattern recognition for PMSM used in more electric aircraft. In Proceedings of the IECON 2011-37th Annual Conference on IEEE Industrial Electronics Society, Melbourne, VIC, Australia, 7-10 November 2011; pp. 3452-3458.

44. Ebrahimi, B.; Faiz, J.; Araabi, B. Pattern identification for eccentricity fault diagnosis in permanent magnet synchronous motors using stator current monitoring. IET Electr. Power Appl. 2010, 4, 418-430. [CrossRef]

45. Ebrahimi, B.M.; Faiz, J. Feature extraction for short-circuit fault detection in permanent-magnet synchronous motors using stator-current monitoring. IEEE Trans. Power Electron. 2010, 25, 2673-2682. [CrossRef]

46. Quiroga, J.; Cartes, D.; Edrington, C.; Liu, L. Neural network based fault detection of PMSM stator winding short under load fluctuation. In Proceedings of the 13th Power Electronics and Motion Control Conference, Poznan, Poland, 1-3 September 2008; pp. 793-798.

47. Rosero, J.; Cusido, J.; Garcia, A.; Romeral, L.; Ortega, J. Fault detection of eccentricity by means of joint time-frequency analysis in PMSM under dynamic conditions. In Proceedings of the International Symposium on Intelligent Signal Processing, Alcala de Henares, Spain, 3-5 October 2007; pp. 1-6.

48. Rosero, J.; Cusido, J.; Ortega, J.; Romeral, L.; Garcia, A. PMSM Bearing Fault Detection by means of Fourier and Wavelet transform. In Proceedings of the IECON 2007-33rd Annual Conference of the IEEE Industrial Electronics Society, Taipei, Taiwan, 5-8 November 2007; pp. 1163-1168.

49. Rosero, J.; Cusido, J.; Garcia, A.; Romeral, L.; Ortega, J. Detection of stator short circuits in PMSM by mean of joint time-frequency analysis. In Proceedings of the IEEE International Symposium on Diagnostics for Electric Machines, Power Electronics and Drives (SDEMPED 2007), Cracow, Poland, 6-8 September 2007; pp. 420-425.

50. Barendse, P.; Pillay, P. A new algorithm for the detection of faults in permanent magnet machines. In Proceedings of the IECON 2006 - 32nd Annual Conference on IEEE Industrial Electronics, Paris, France, 6-10 November 2006; pp. 823-828.

51. Rajagopalan, S.; Aller, J.M.; Restrepo, J.A.; Habetler, T.G.; Harley, R.G. Detection of rotor faults in brushless DC motors operating under nonstationary conditions. IEEE Trans. Ind. Appl. 2006, 42, 1464-1477. [CrossRef]

52. Ierardi, C.; Orihuela, L.; Jurado, I. Guidelines for a systematic review in systems and automatic engineering. Case study: Distributed estimation techniques for cyber-physical systems. In Proceedings of the European Control Conference, Limassol, Cyprus, 12-15 June 2018; pp. 2230-2235.

53. Moher, D.; Liberati, A.; Tetzlaff, J.; Altman, D. Reprint-preferred reporting items for systematic reviews and meta-analyses: The PRISMA statement. Phys. Ther. 2009, 89, 873-880. [CrossRef] [PubMed] 
54. Nandi, S.; Toliyat, H.A.; Li, X. Condition monitoring and fault diagnosis of electrical motors-A review. IEEE Trans. Energy Convers. 2005, 20, 719-729. [CrossRef]

55. Heydarzadeh, M.; Zafarani, M.; Akin, B.; Nourani, M. Automatic fault diagnosis in PMSM using adaptive filtering and wavelet transform. In Proceedings of the 2017 IEEE International Electric Machines and Drives Conference (IEMDC), Miami, FL, USA, 21-24 May 2017; pp. 1-7.

56. Isermann, R. Fault-Diagnosis Systems: An Introduction from Fault Detection to Fault Tolerance; Springer: Berlin, Germany, 2006; pp. 1-475, arXiv:1011.1669v3. [CrossRef]

(C) 2020 by the authors. Licensee MDPI, Basel, Switzerland. This article is an open access article distributed under the terms and conditions of the Creative Commons Attribution (CC BY) license (http:/ / creativecommons.org/licenses/by/4.0/). 